とと表 $の$ 的

し $ら$ 報 方 櫝

七熔、文面沜

舉 岩篦にのに

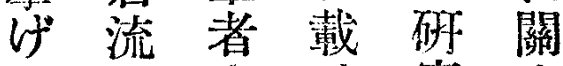

擝 ら の 自せ究主

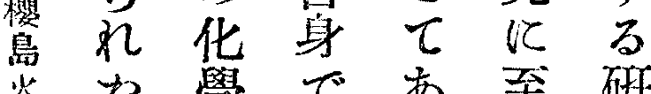

火て學であ至确

签櫻 成 行つり 究

緒

地

鳲分 $っ \tau \tau$ は

類をにれ、は多

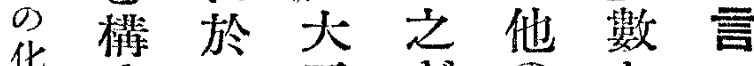

學成立正方の あ

的专、熔本火了

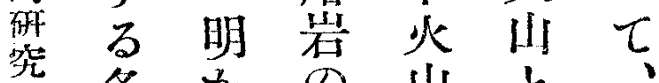
各加の 山と

熔ま數の同诛

岩る種贸 椾に

類相の石葚大 の異 分學 た正

穓艺析的少

出認 の 呼年

のめ結 塋くの

封放果上し噴

代ばと參て灭

江宗妾洘、以

上 5 比文唯 乘

る外輘索地各

酸 事しる質種

性實 て 量 調 の

度に居重香調

の遭万学所查

變遇內るで報

化 ᄂ 唯行告

1, 一 壮加

就嘗東の澄

て側凟九表

の小面料大世

記藤飞で正ら

事先滀あ熔れ

楿生流方岩视

一起隫色。分居

乙 灭第筆 析 る

ての—者のの

興 輪期故結に

味䞡と此果、

櫻

篹

熙

党

雜

言榓

灾

然

III

公

熔

岩

類

の

化

學

的

拾

四

然

第

四

百

號

研

$\overparen{-1175}^{3}$

至和

理 管

早

士:

行作

山

口

をの 第の 方 其

覺 著 三分同 化

之例 期 析 所 學 
概 鉴

括浩 垭

的孛算

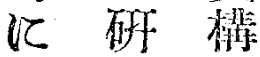

擧 究 造

げせの

之る -

江多船

對 く学 篦

しの 逝

て著べ造

筆者る

者のて に

の 斷亡 す

信案故る

寸゙の記 從

る 根 战 爽

各據の の

熔と順知

岩度識

流和字

噴るし

出事

の 項必

順要

序批で

孛制 あ

述方る

今るか

ると茲

丈とで

に 8 精

留止し

め

置唯江

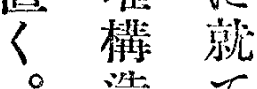

造宁

關 吢

ᄂ る

ᄃ

發

表社

出

れ來

九疗

意的

見。

学

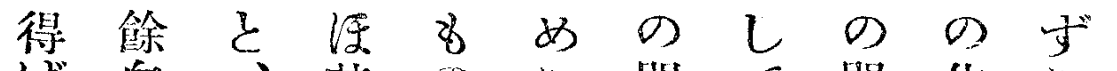
ば白、其のに間て間化に 筆を地本学、題居, 題學任 者借質ば引後就を成居

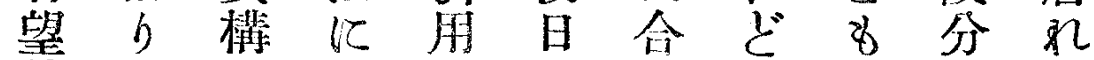

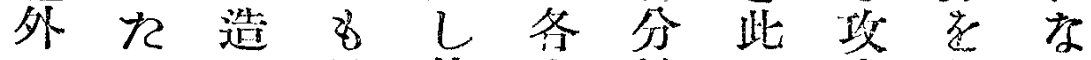
ののに足他方鹤の觉知少想 地仕 は關 ら の 面物方方るつ炎 合先し泉三のの面るの出

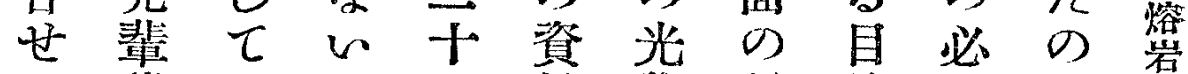
で諸は・光料學詳的要で数

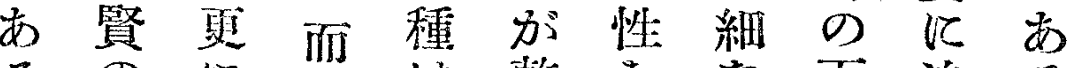
の 记しは整を古下通方华

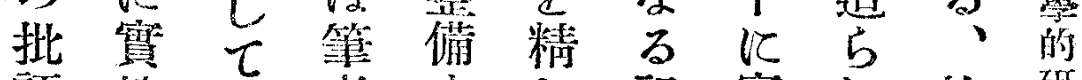

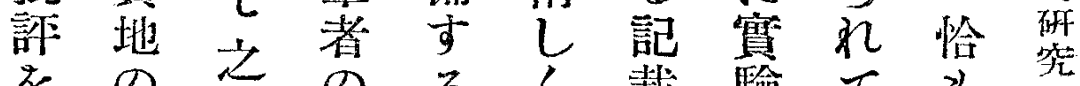

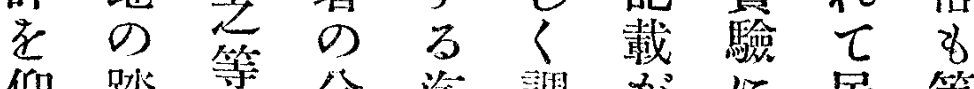
仰踏等分迄調吕に居筆

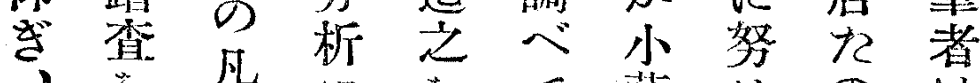

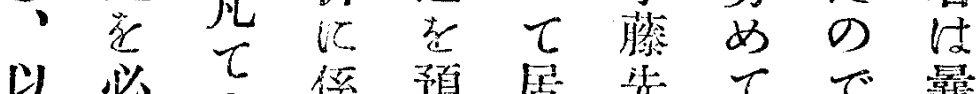
以必の係預居先てで暴 て整のる持生得、江

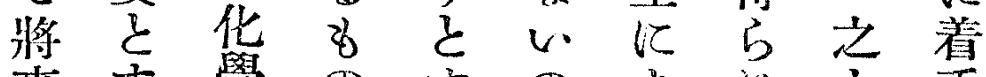
相學の方の机主 䃏る成でるとつ施同せ

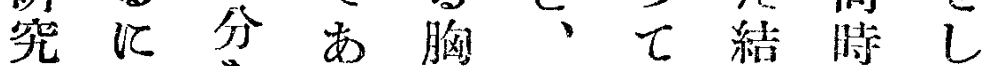
上至古算火公果儿熔

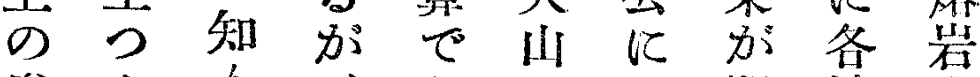
參光 $h 、$ 市

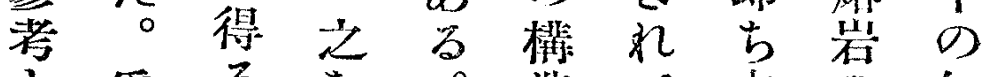
子爱る在。造七本句包 しにの地次江居稿化襄 そ不恃買章關る で學物

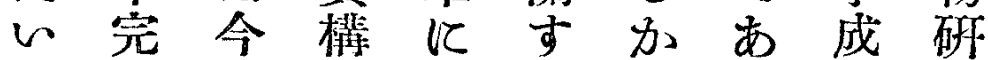
主全後造揭る らる分究 旨乍餘方 げ研复。加の 飞ら程研し究に筆時一 外從の究分加は者代過 存乘努世析简殆壮之程 ら調力 $力$ 表医ど熔共と 奴查のと立岩にし

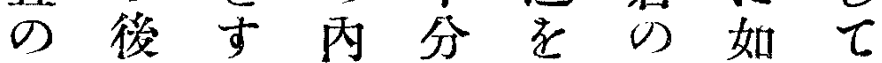
幸結尔当に省薄何全 ひ果な試種進略片に山 に齐け料は捗しを戀を 識纆 れ $飞$ 地 者めば比質て 又通し成 のて 尔す調居岩ら乘す

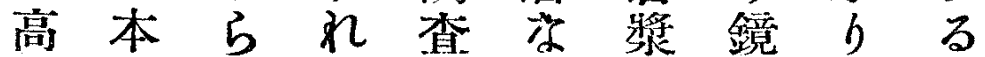
教誌权ば所以分检 し 岩 をのの仯の䍃化庄兮石 


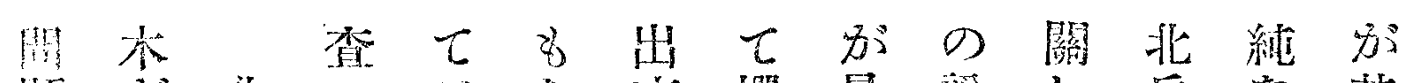
題吕北

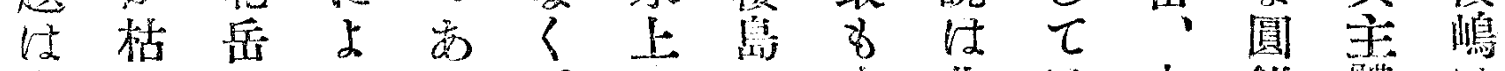

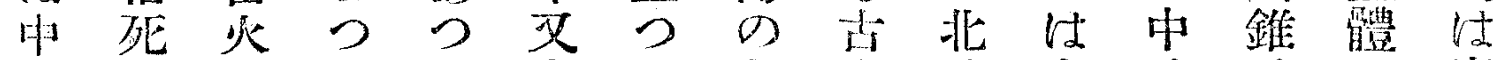

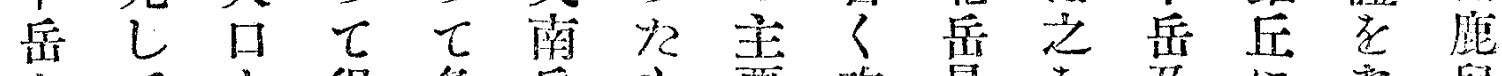

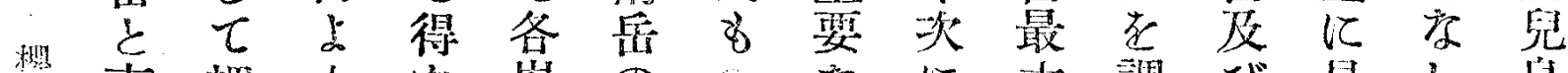

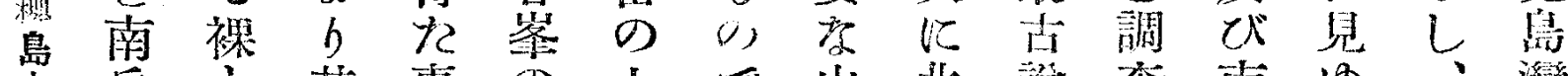

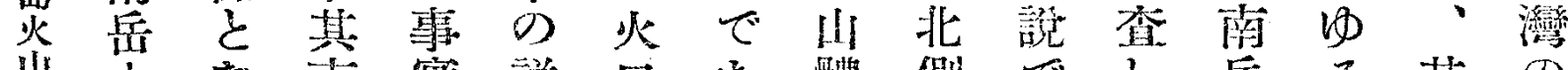

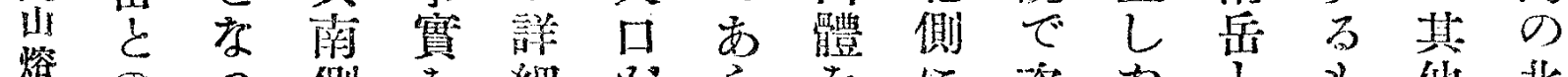

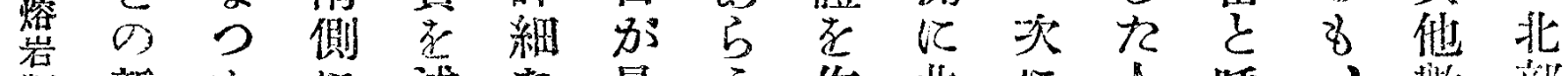

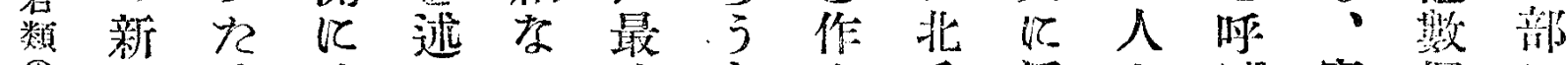
の鹪時流べる後とり岳活々ば䨘個に

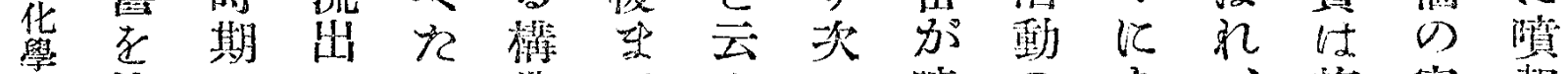

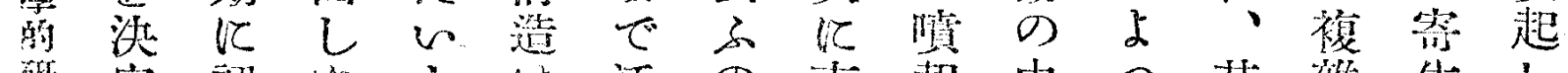

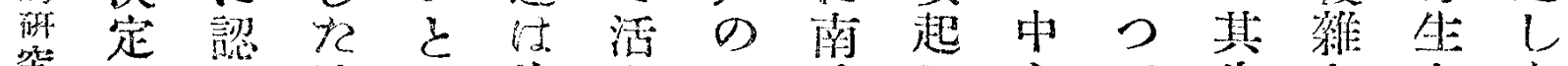

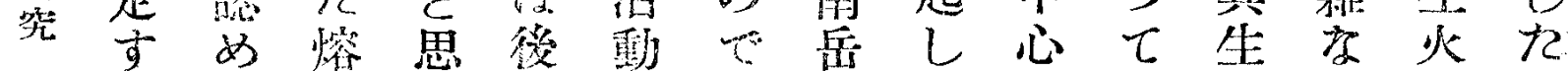

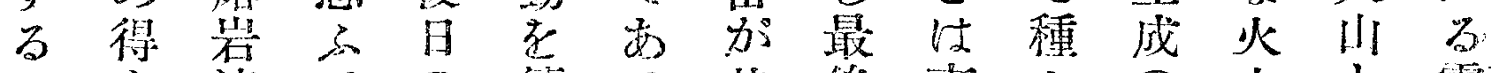

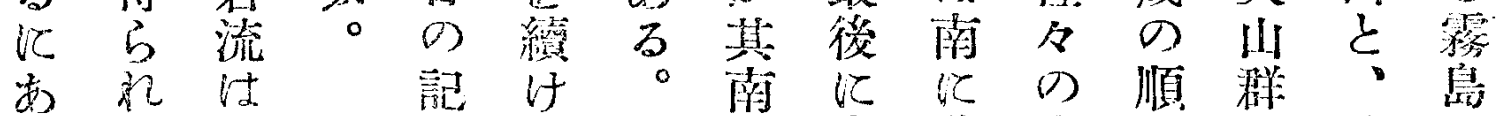
b) th 明

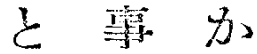
世筫保 らで 中 れ方岳 名莡 小。び 藤故膈 先に岳 生北熔

の岳岩 御 加 意最被 見初德 江 せ 情出 等桃就 者九て 3. $ᄃ$ 居 闹衣当 威はと で疑衣 㐫い、。 三名等僳 然 所 後 る で にあ 全 中? 山 岳ての 熔、草

工 《居上飞岳動見即 $b$ 飞嶃

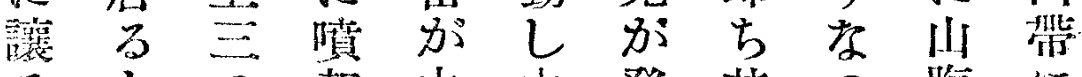

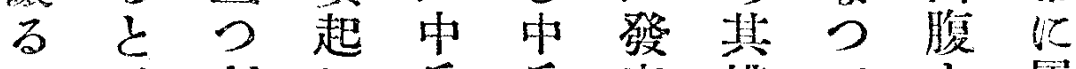

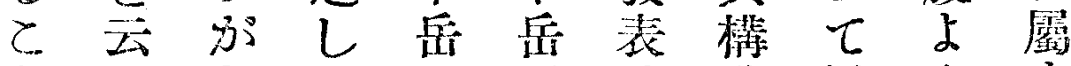

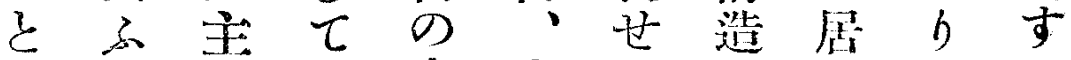

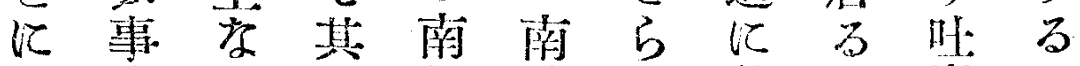
實子南側原れ就。出一

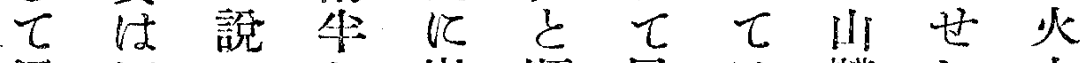

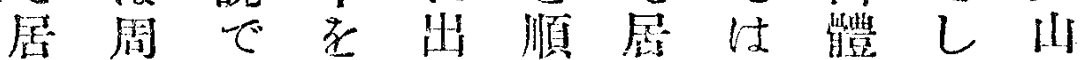
万知市被承次万来》熔舄

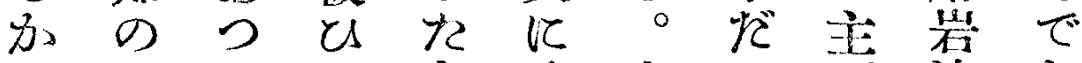

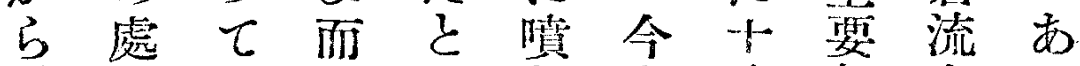
茲落献云起分部と口 で市岳て るし等明でよて 性る加後說九の市b

各。最恐でと結でる權略

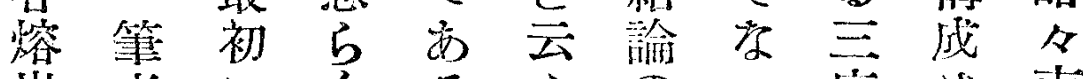
岩者飞々る交の心座を南 流击中。の至所出挑 の回桃岳第で旨加圆てに

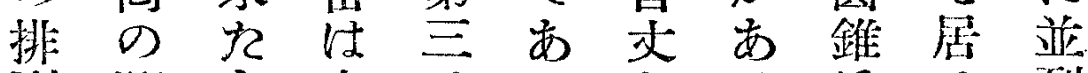
列㸴之南生了后了列 《究主岳北。摘の戊名世 關を張の豈第記で其のる 乙熔主生加吉、位で三 几岩万成最可烦置個 筆流人匹初戝代比外の

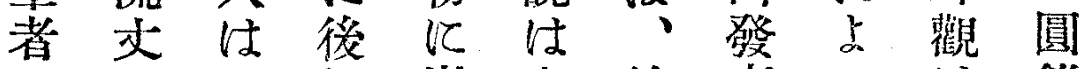

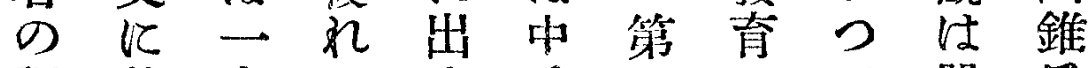
調就人 $\tau$ 承岳一匹 $\tau$ 單岳 
活をるの尔 就岳つをでらへ岩 動的時有遺文以てと制中南ばと

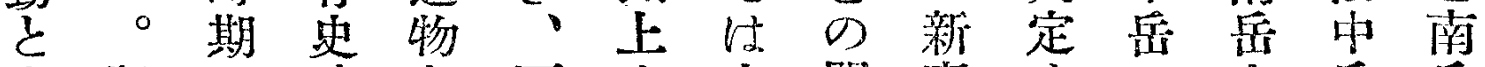

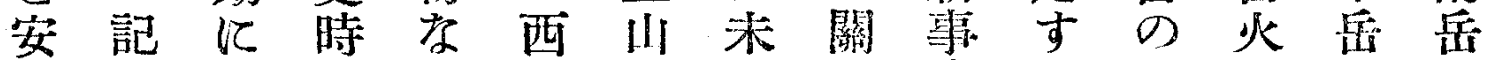

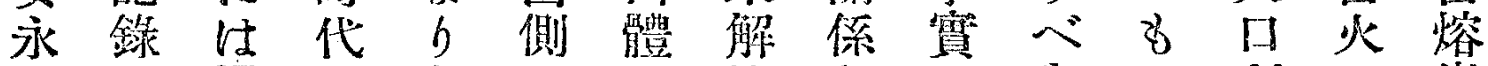

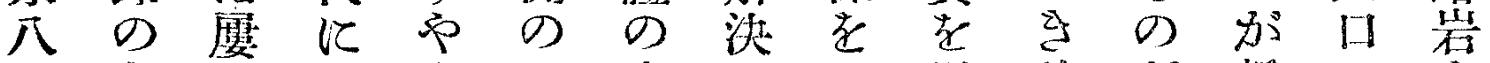

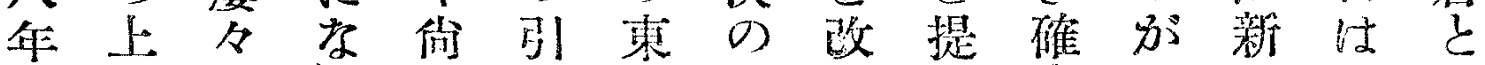

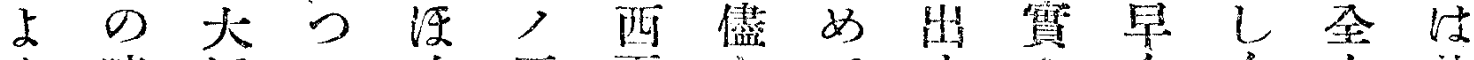

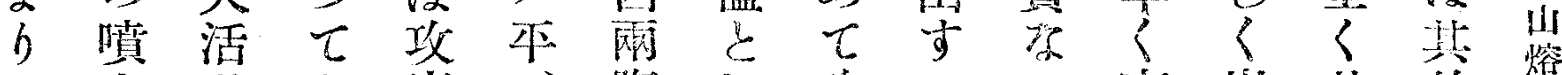

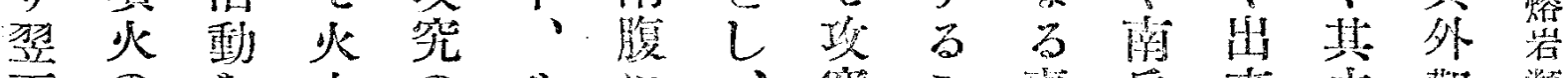

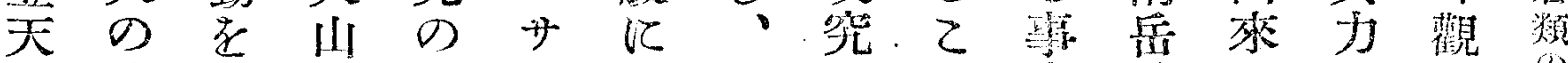

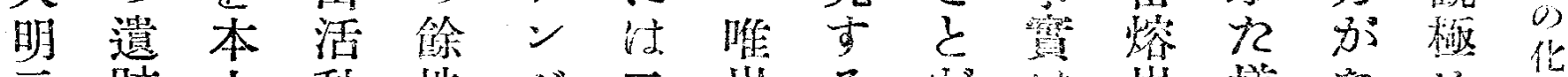

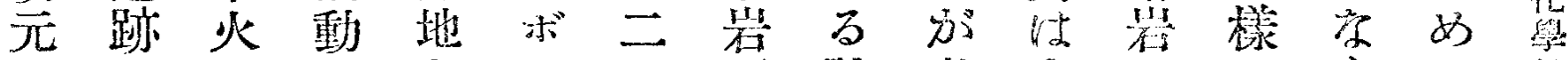

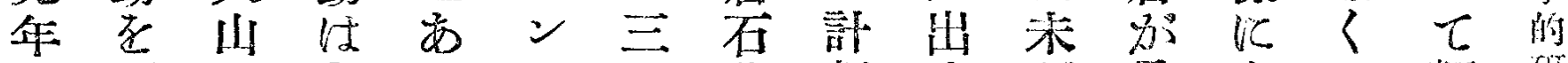

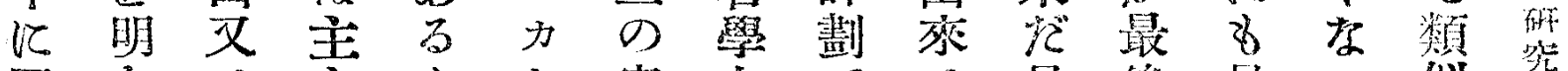

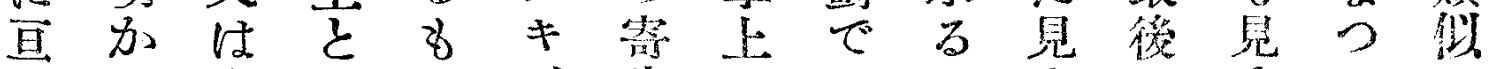
つに附しの、生の市当出にゆてし

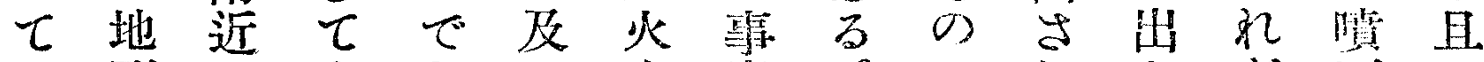

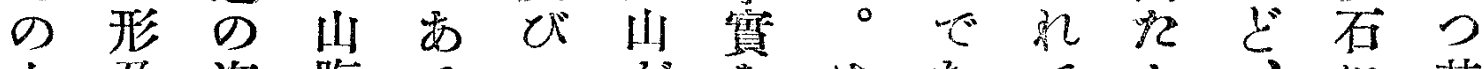

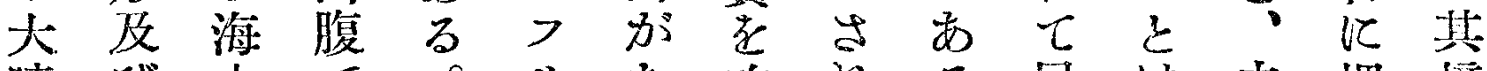
噴び中で。リあ炏れる居壮夫埋境

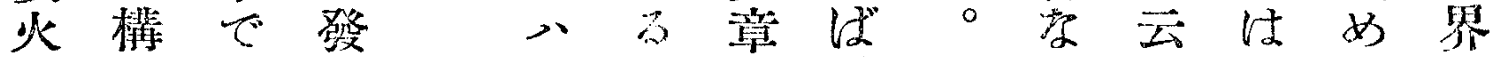

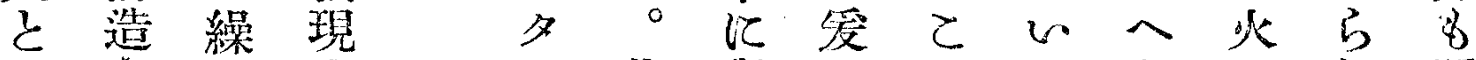
で上返主 あ にしる つ指放栐

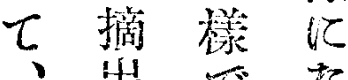
此來方方 のるれ 网 の 四杜其記 交 等 錻 紗 明活沉 動 三動 あ 壮伞の方 大文中和 正 b 心 銅 三同 分年 年八何間 の年 處占 活ので

動 間 あ 天 ににる 尔 元 起各寶 敵 万追字 卞方跡年 る 數 各 間 程、次出に 度の 來 亘

此擧に房の等口礼明 熔のぐは次でい加督膫

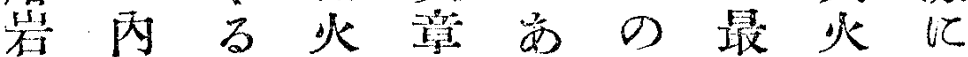
上東文口にるで後口虽 b 側に壁說。支壁壁 疗の留附了然るで南主 $b$ 鈿め近所 $L 。$ 淤侧 $る$

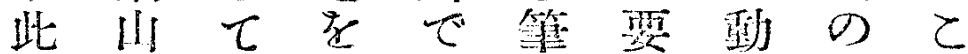

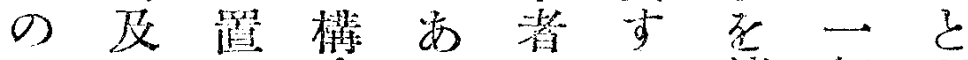

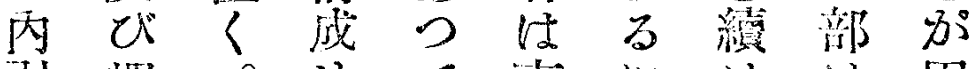

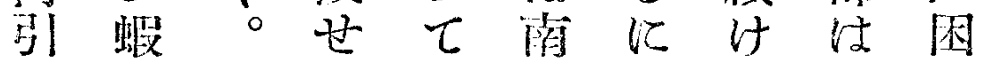

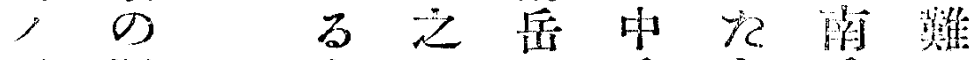
本塚中学 岳亡雷で

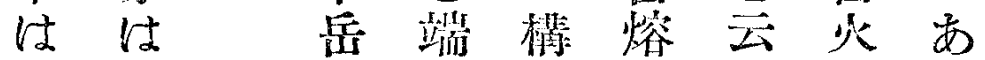

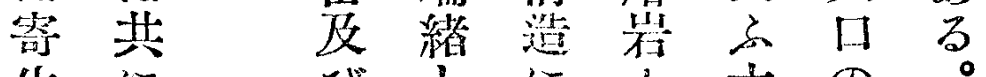

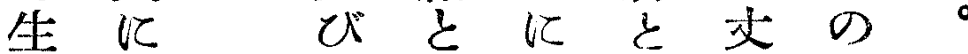
火浮南し關雷で雼火 III 石岳てし岳市め口

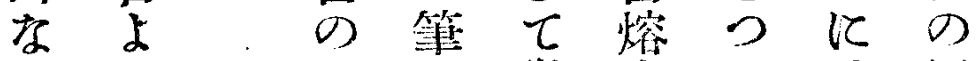
b b 雨者從岩破活

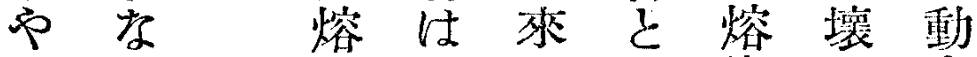
單 b 宕 更知 岩さ力

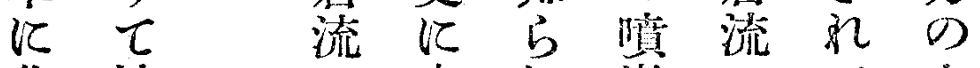
北熔 の中被出 岳岩新岳ざの些愿务 熔流舊子る 前出る ら 岩江南—後岁方云

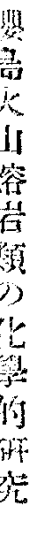


に 量 鐵

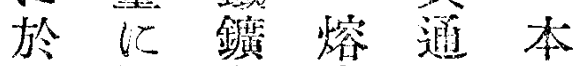

$\tau$ 關と䂟な龺

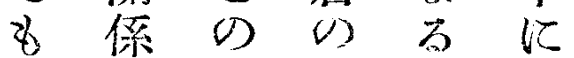

其守分色肉於

表る量 跑て

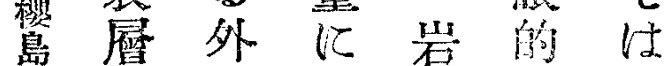

苂石支石特各

豁基配 $の$ 徽摈

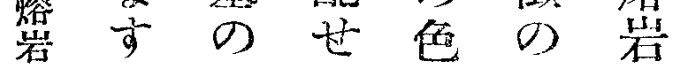

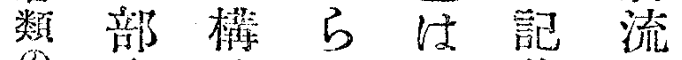

分浩吕夆戴

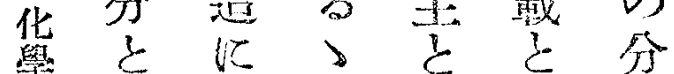

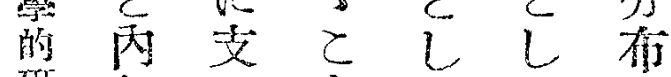

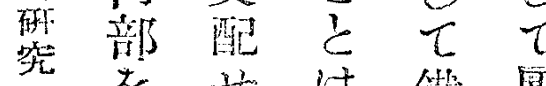

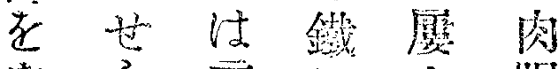

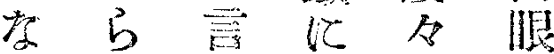

寸る 老占學的

處了俊尚げ型

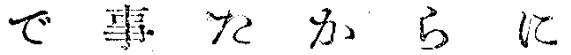

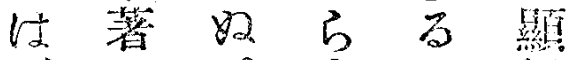

石し。完〉微

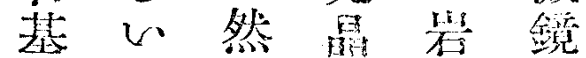

の 8 万梊石的

色のに留の特

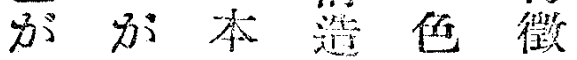

䇏市火のに应

しる III 倠 㩆

< $の$ 不 $、$ 化

買今熔でて學

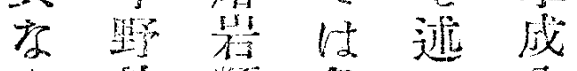

b 外耀色心等

前での $0 て$

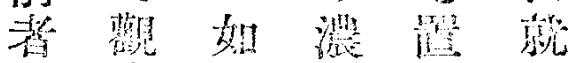

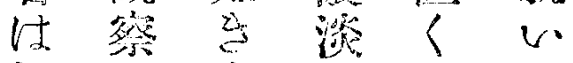

照し玟: 快必て

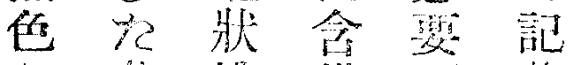

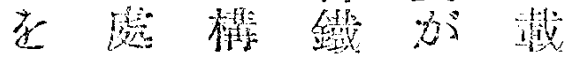

呈 6 造 领丞

马劣物るる

る和乲期。の

のばす范で

五に熔 8 鐵市

後岩の萜手

者流で士 品

はの注珠先

䁫游同绝酸要

色一汒領 全

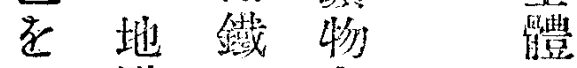

存點 の $と$ に
时後世之别る消の

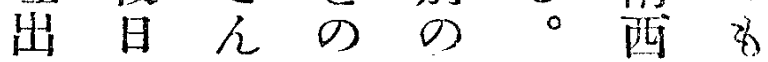

に其と間出之のの

係 研高儿乖等山で

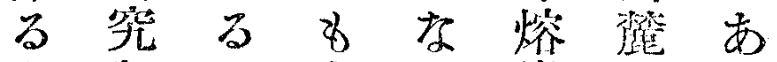

子存の

の完加々程流流々

各に成其成類の记

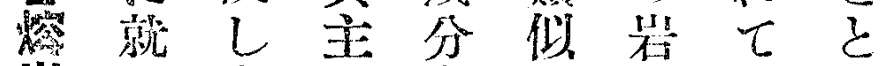

岩豆古亲上世石多性

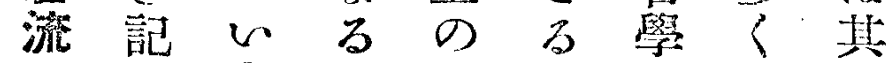

○载之目相名的は明

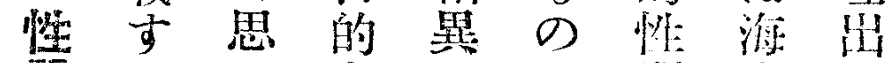

罡るふと起で質中し

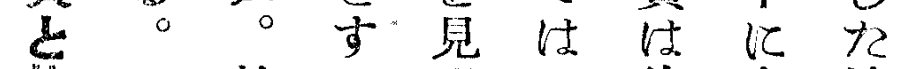
鹳万出古後笑熔 に方 し れ 管入岩 本の得と述し流 稿で当化 ぶ兄方

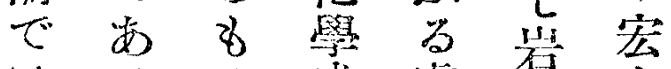

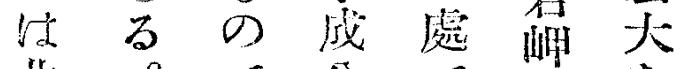
北。で分で范索 岳以市の峦督る - 上方上沓造默

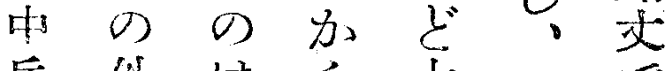
岳外はら大低

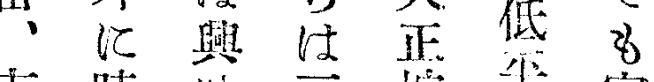

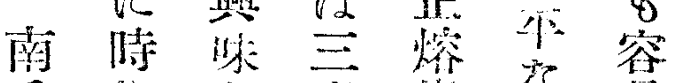

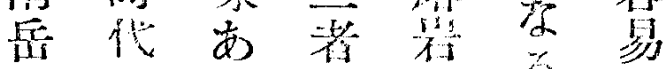

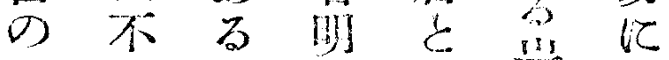
各明乙加其售推 聺 $と$ に

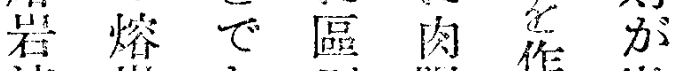
流岩出别胀作出

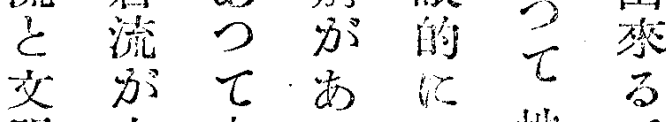

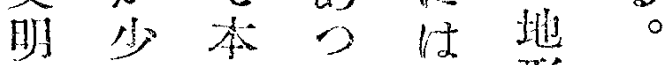
乙稿七訶形之

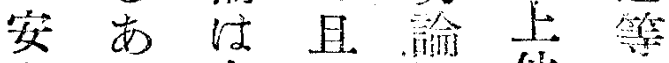
永れ文品他 艾 ど等 北微

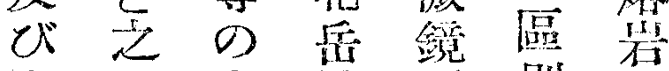
大は事熔卢别流

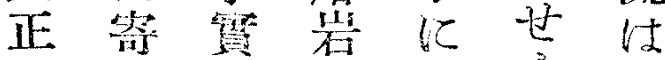
の生文文於 5 泉 三火忠病七る 大山筫䨋方方東 寶と儿岳殆の北 火共記熔どて苂 のに載宕區新谓 


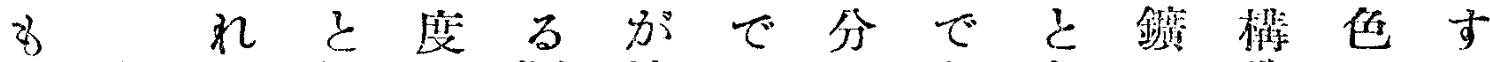
の以る思の獨塊はであなの浩のの 8 下 8 低蓝狀不 あ各の 誤下 せ の 基䥫。龺何化一 る熔でるにるる 事営あ傾よ熔の十他にる之關あで

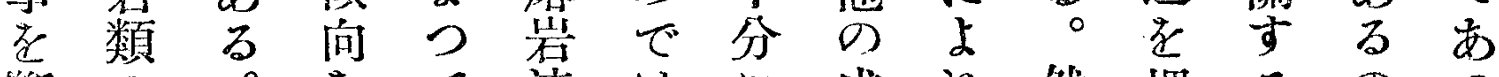
斷の。老て流は成行然埋るのつ

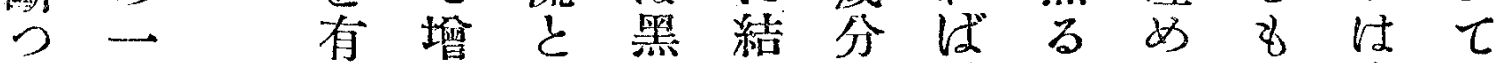

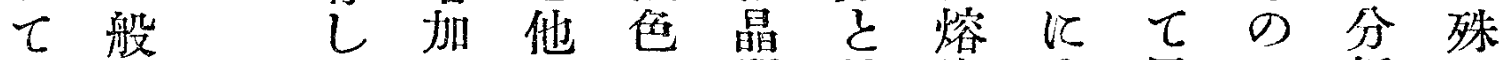
置・の 特

性 蓝

化

學

成

分

花

順

次

淕

㵶

南

万。

但

記

戴

便

宣

E

I*

L

ह)

貲

出

の

順

に

存

כ

$\tau$

居

疗

w

疗的

且每見

での

亦岩在

占石・區

亏品

加

。象す

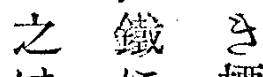

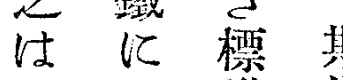

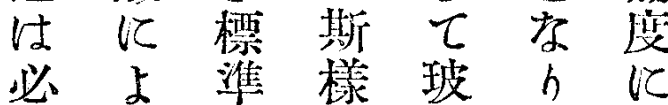

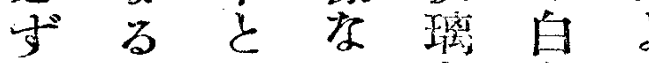

乙 $九$ 理 $己$ 色

方云 $\tau$ 由

正高恬でて

確乙殆色

で そ

少分價

的值

場“岩察

合不

合售尔流

亦色的

る加の局芝在

乙 暗で部

墨变

飞る變

本な

火

岁装全等

熔等徍特

岩程多徵

飞一鐡と有

層合性

基会势

性量

敉の劣元

के 酸 है

b

の 性
の

丽

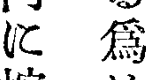

熔

淡

込色

几を較

字的

特尔

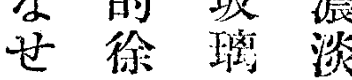

の熔飞久

冷

欠 济

、ばよ

色棠

却 $\tau$

$\tau$

寸 不

不全 全

工 附

のし 居

要

及 石 斯

或之愿部
の 山 岩 化 學 的 研 究 西 
埋壮色ど

北吉南儿 苫る岳着

山玻熔色岩

體璃岩せ流

齄

島

火

山

熔

岩

9

貨

的

碎

(

数名中處表複 万乲岳加層輝

所趽多妾石

で岩い等宾

探、儿。高 III

集玻於鏡部岩

し璃け下分で

んはるではあ

主朦場疗石

要腈合紫基

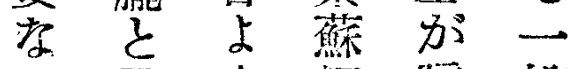

る曒 万輝曋般

陚分幾石黑飞

料て分の玻斜

儿透罗量理辰

就明公在㹂石

いで樣普での

て李飞通あ玨

化心思輝つ晶

學。应石 $\tau$ 加

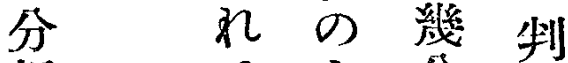

析る夫分然

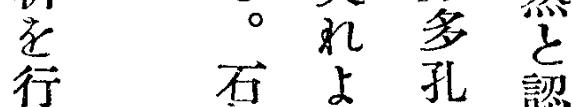

つ基 $b$ 質 蝶

れ、遥でら

結䍸吕亦

果記飞る。

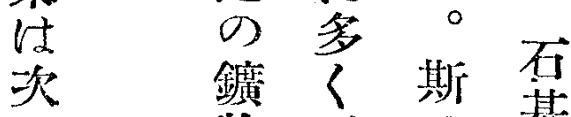

の物、基

通分又部は

で微秛分通

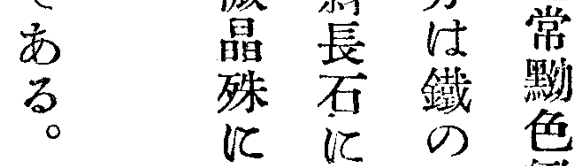

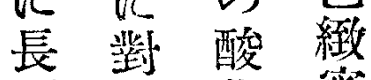

石等华密

の 3 《

微輝文名

晶石つの

$\zeta$ 類 $\tau \tau$

之赤亦

量褐

のつ北止

餘 $\tau$ 端 つ㸮 年 北 地北割 加岳石 松其 $の$ 火 あの 㥓 本咢の熔口 る山、、为碞よ 腹北力向流 品 岳 に江四二 ら熔, 當被周二 吐岩等る 敄に 出上の 舜 さ流北 さり高宕れ下 れ 棈地 III $\tau し$ 岳 れ成老杜居

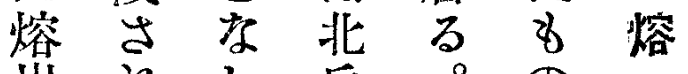
㹈れし岳。の 各て、熔北で岩 ら居北置岳、 成る 侧 の 山其

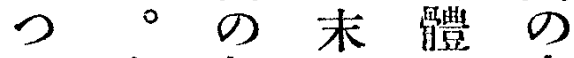
$\tau$ 帛 部 端 南 居の落少南 側 る西松 ら西比 側浦索腹 㨁 又のよるはち 此破 b高著に の壤三地し中 附导侯でく岳 近风、亦破及 のた白る轅 び 引處澒。南

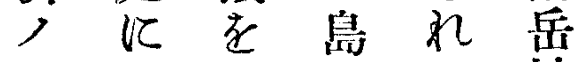
平は經のて 熔 注、西此岩 奇フ高北のに 生》凂で部被 火八には分は 山夕、至熔に氺 呼サ学間岩厚北 ばンは沬東 れボ海愛喷 の てン岸宕石山 居カ们摩腹 るキ迫との壮 が口つ同露文 劣 高 $て$ 樣 出 明 㾄地島版 調 加の腹 あ 安 查あ最でる永 


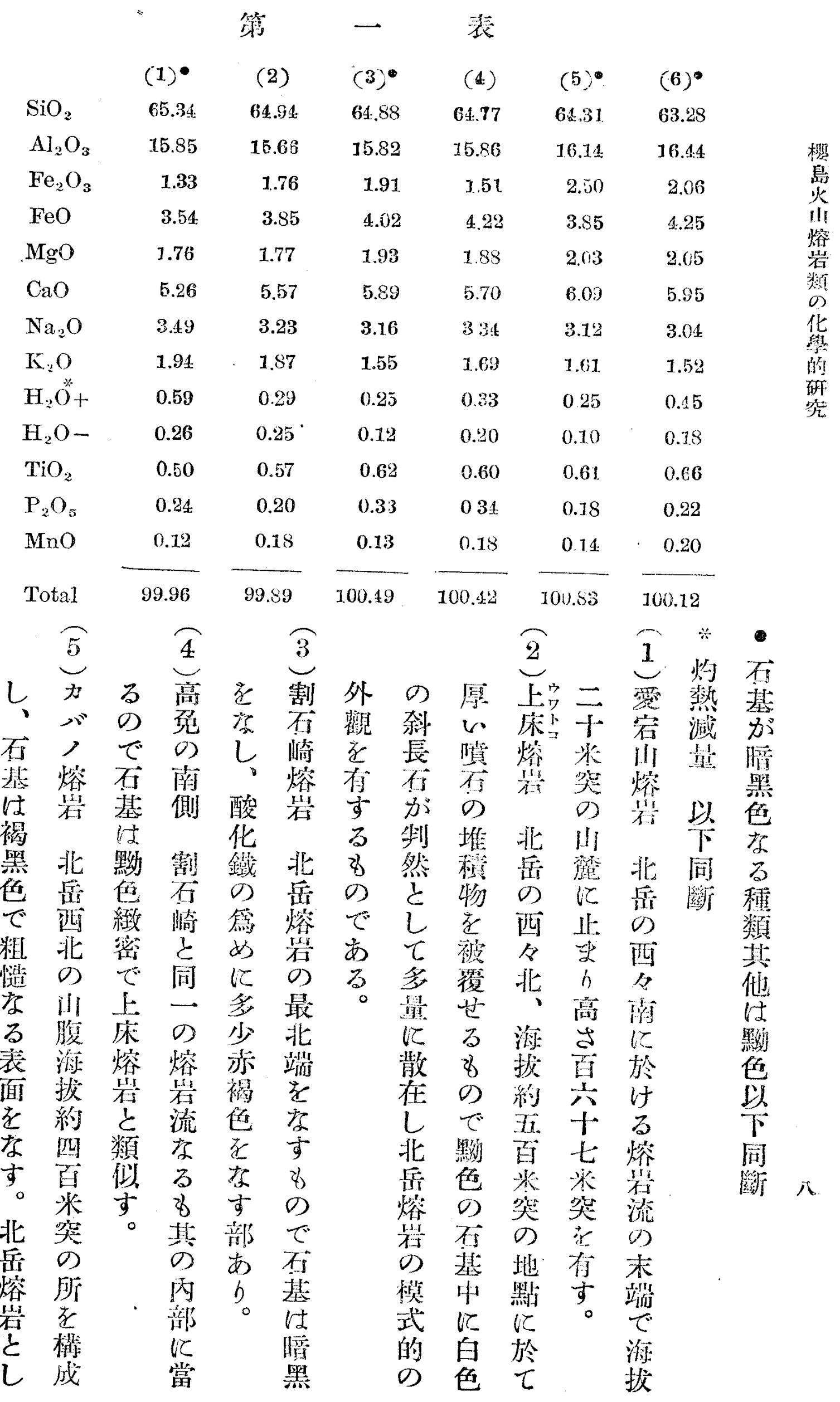


活市引の

頂るノで、茲

上。本あ比

附又のる 所

近南南。䍀

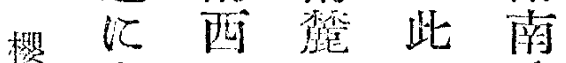

品大でにつ岳

火崩流熔焙

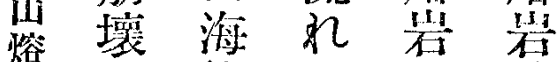

岩拔

類る百曖社二

化跡王宕 北 型

然

的

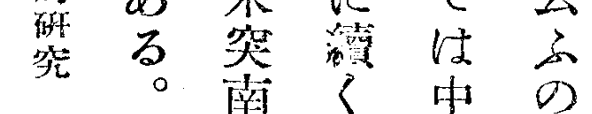

南僛北岳は

岳で岳熔南

火情熔岩

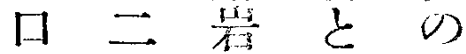

の百を芒然

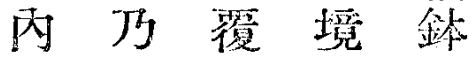

壁 至と 界 火

诘二兩分口

籐百者明另

者五のでら

分十榄 流

大米造く下

正突谷、し

四の孝钬九

年山俗者名

の腹にとの

三儿犬共で

月步路に從

下 分让 棑

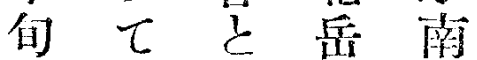

伙後稃熔

火期 し 䂟 铲

口草 罢

底熔北被

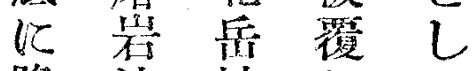

降流熔 乙 乙

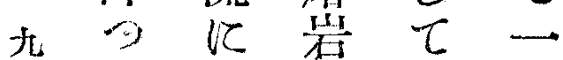

$\tau$ 被の居 般

觀は崖るに

瑤风存。知

し、存西 ら

代東す侧和

所側所 で

にで加は ซ
はす之琵形鐵

否る等 で上の以

丸南局は明幾上

能岳部あで分の

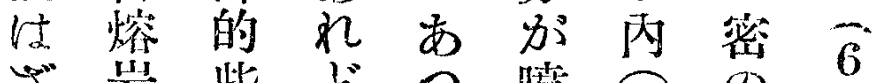

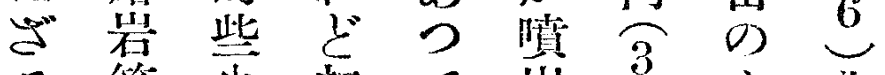

る籍少初て 出 $己$ 北

三事至学 期 2 後 $の$ 岳

實 型 る 垬 2 酸 5 で

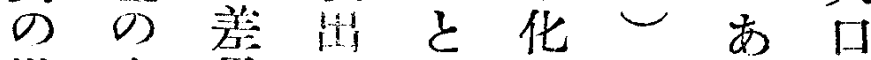

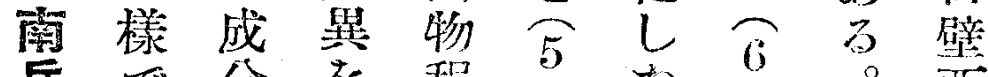

岳で分索程

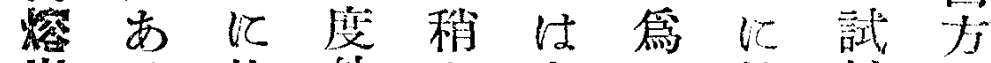

岩る比外々 之於料頂

第。す視酸にで计は毕

れす性亞烈万酸

型ばれでぎ占陵化北

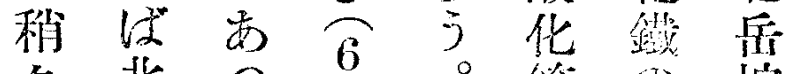

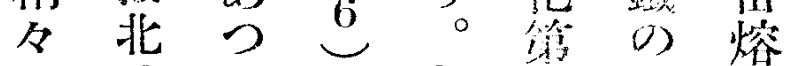

酸岳ては却三䍖罟

性熔㭙最裙鐵內と

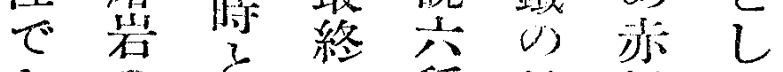

あの 至の種最裀元

つ各共姓の加色怕

$\tau$ 種幾出熔他に最

校分物岩に染後

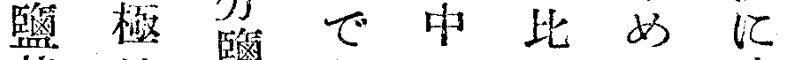

基め整あ $\mathrm{I}$ し 喷

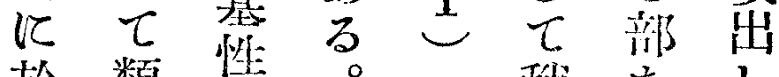

於類整。万熦あし

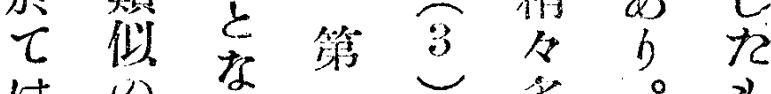

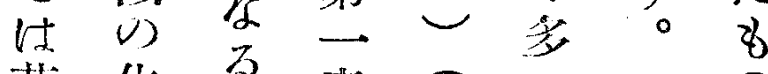

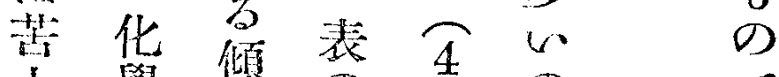

土學倬 の 4 の で

飞成向分情去腷

䈏分曹析最試

及孝古年色

石有訬結初儿向

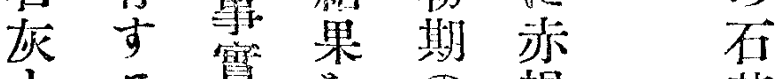

$と る$ 算在の褐基

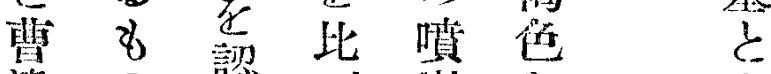

達の認べ出を 小

とでめて标

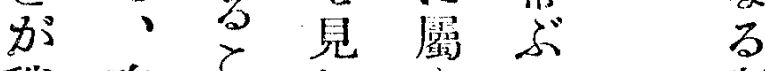

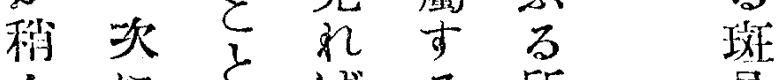

タに

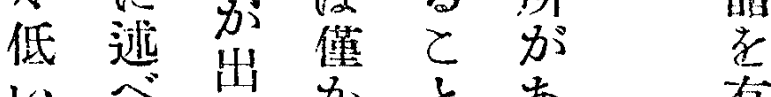

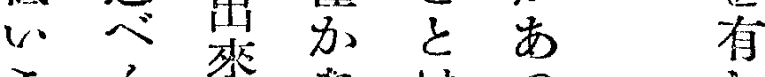

て九來机山つ

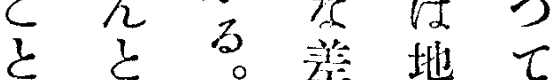




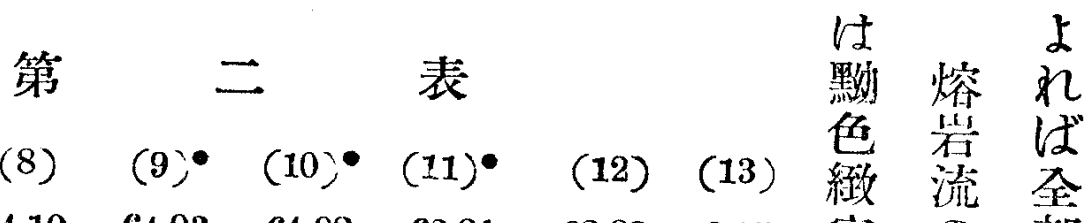

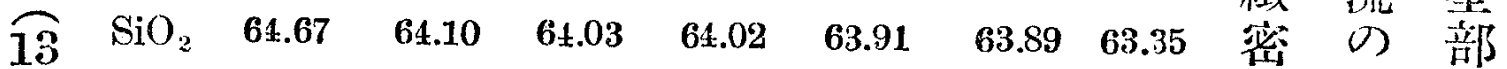

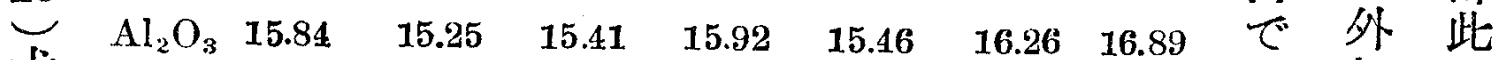

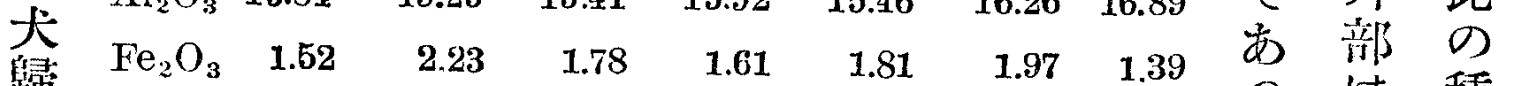

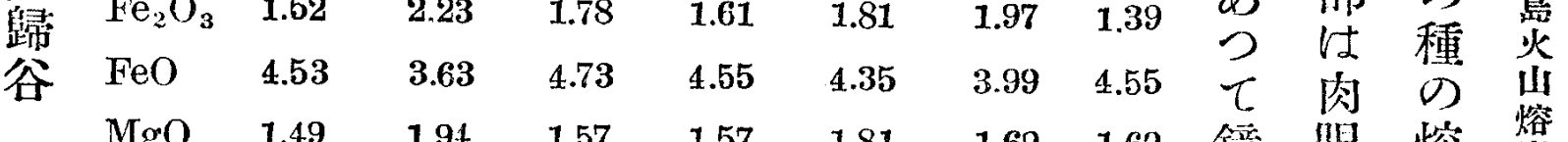

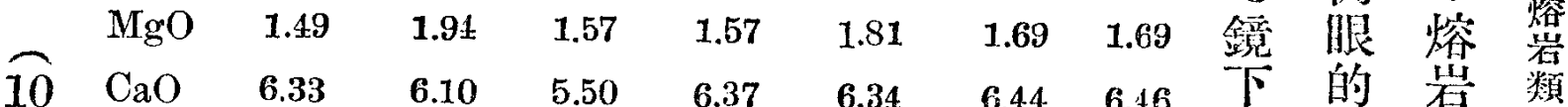

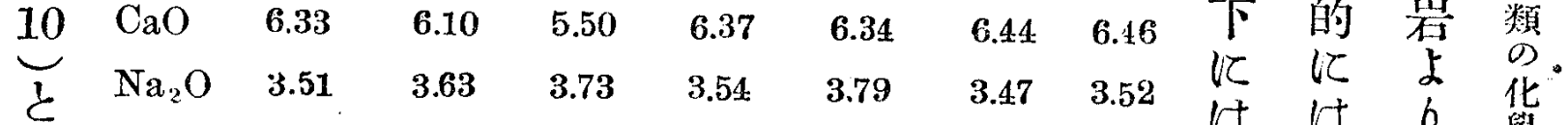

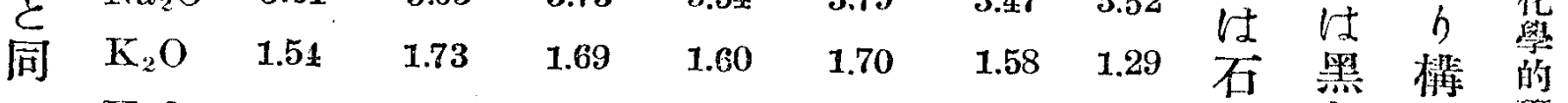

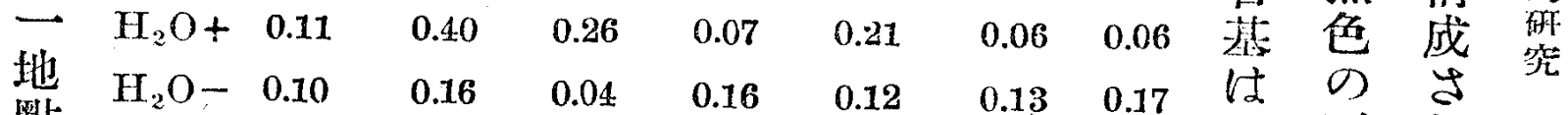

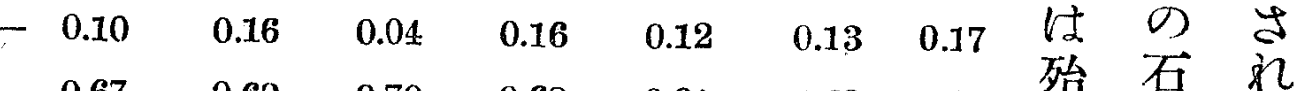

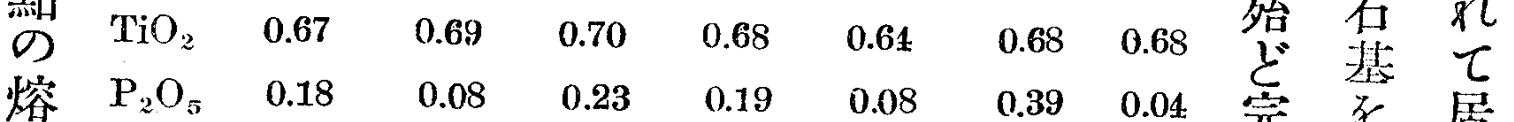

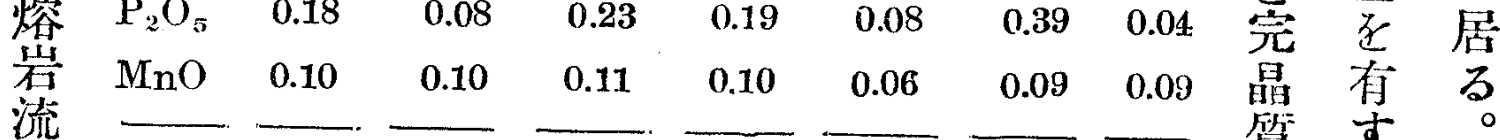

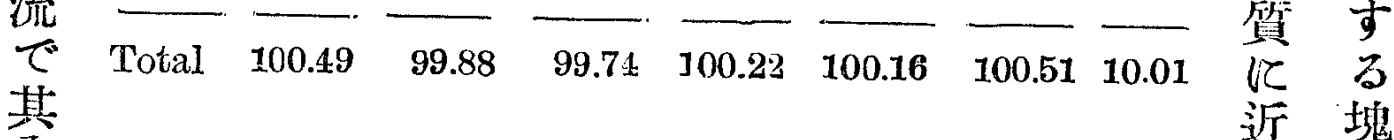

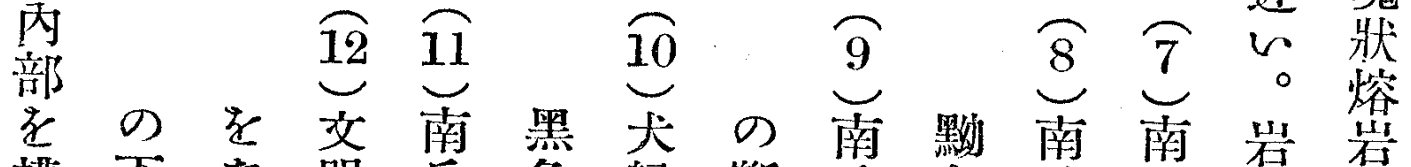

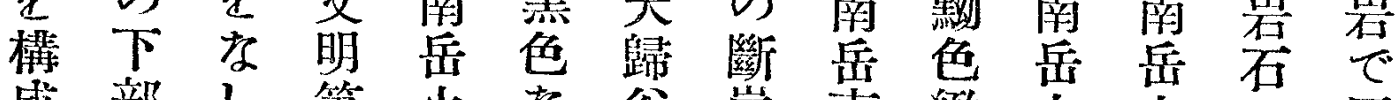

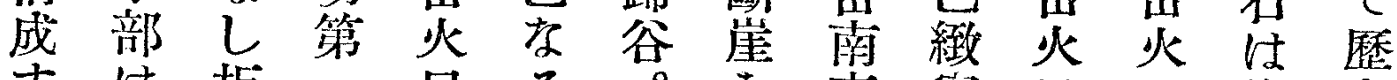

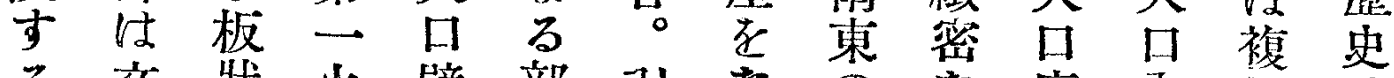
る 交狀火壁部引尔の底肉輝 時 䁫明 節口頂分。弓す出る の 壁石代 色熔理壁上。本熔腹種西の 安の

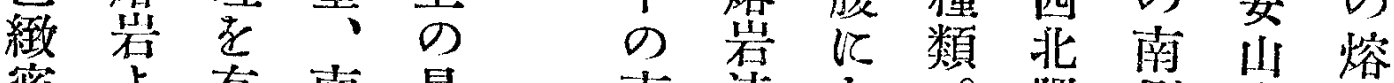
密よ有南最南流あ隅侧岩岩

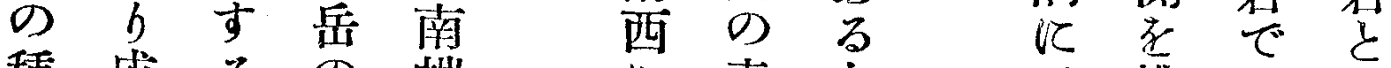

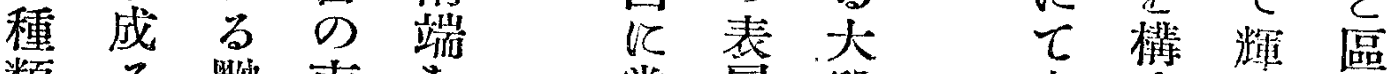

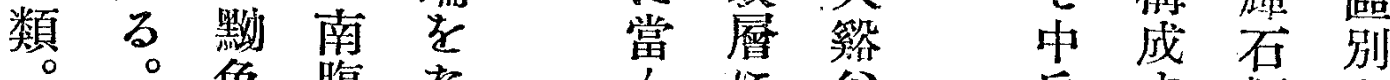
色腹学 多谷岳守類加 緻に主北近合炏る整な

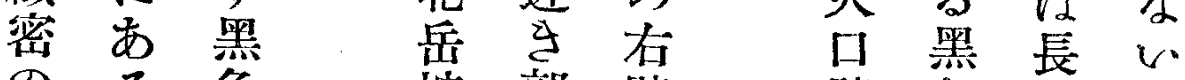
のる色熔部壁壁色石。 8 文熔岩分で熔に而 の明岩存の海直出比 で第砶被黑拢 る

本の

火内

口壁

覆色蓉

。若 米

表。突

層附
真岩

证

當

る

露

出

で
L $\tau$

蜍 焀

程 岩

少 流

なの

有章 


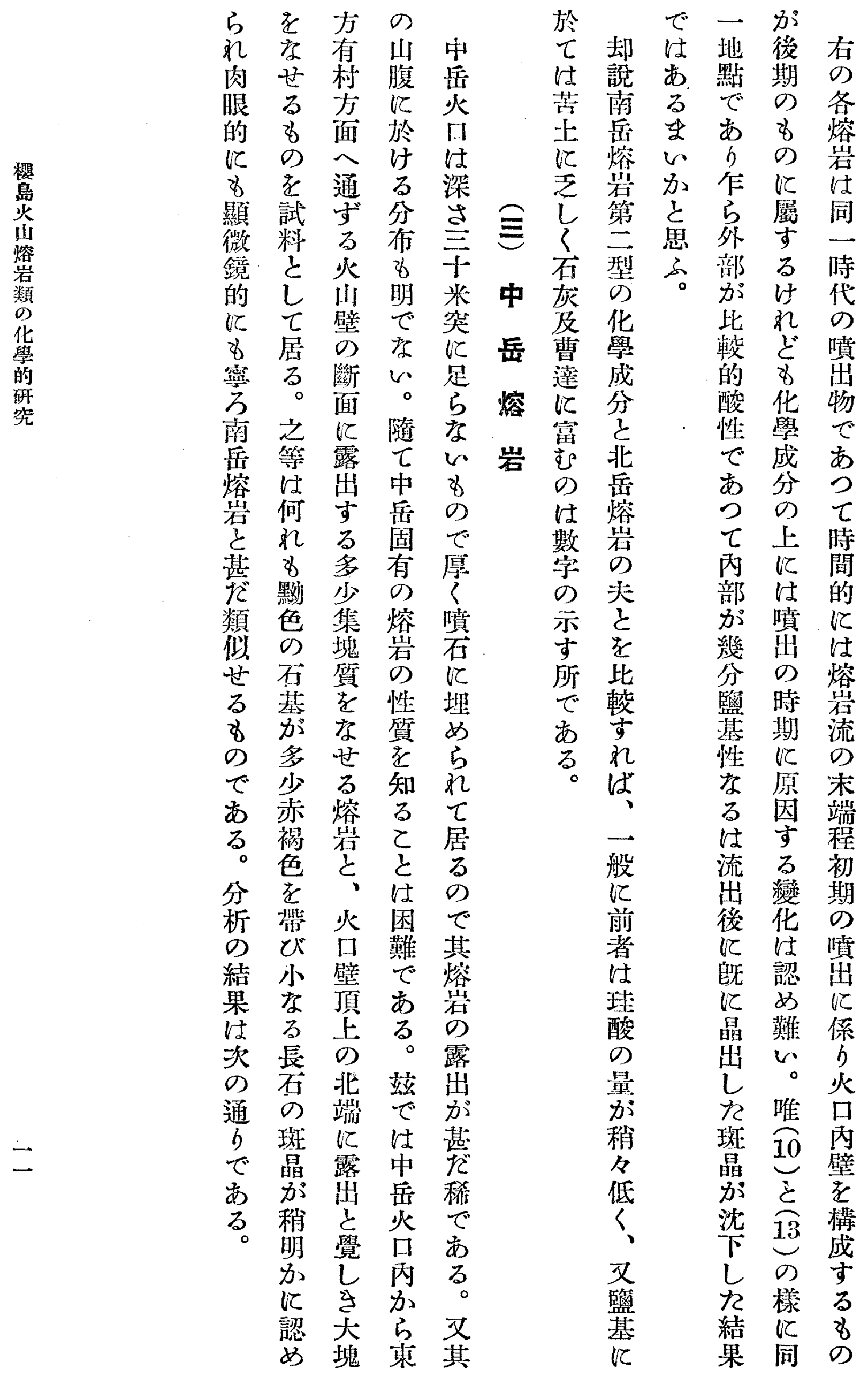


其罚地に岩溜

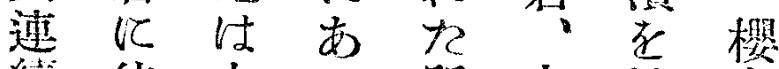
績彷大つ所南缺息

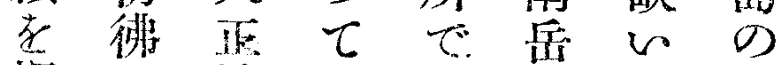

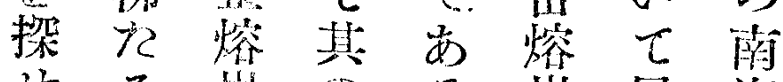
せる罚のる。芣居海 ば敌少。第る等

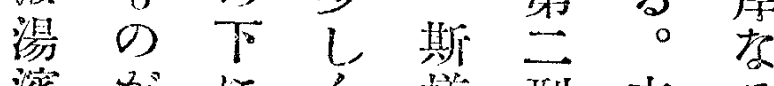

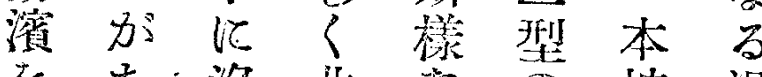

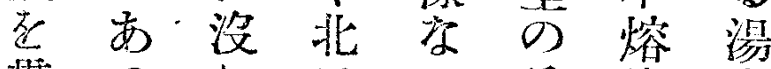

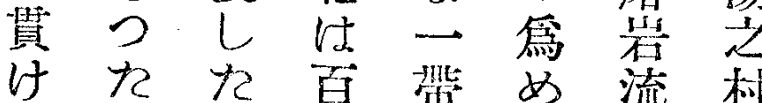
る篇和米范儿の占 河めど、哭劣、西り 底筆琶应世又線觀 花 者超る古㤌音

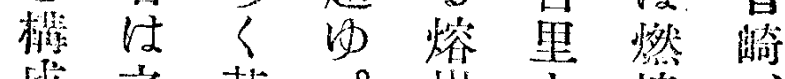
成之其。芣学崎 七薄古流湯范古 又北矕里は演作里

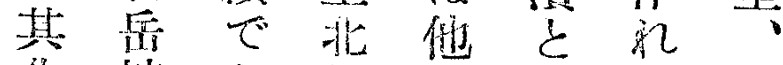
北熔支侧に元公

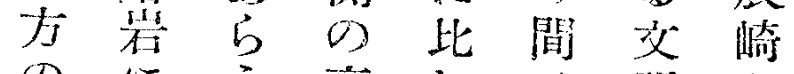

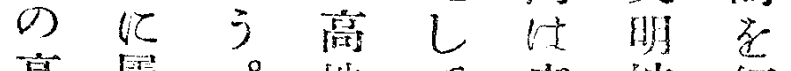

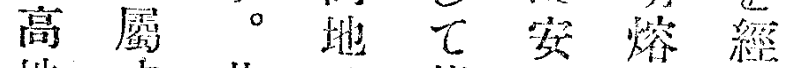

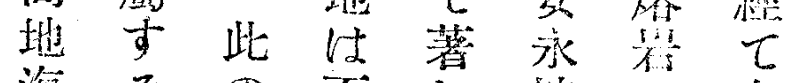
知るの百し䛲儿有

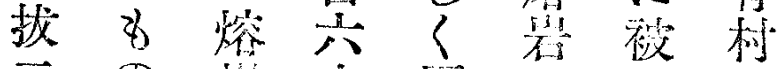

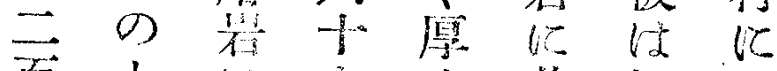

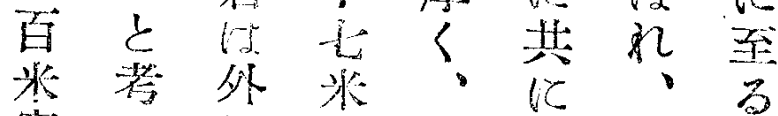
乫人 鹤 笑觀被北 附て南老音は性 近居㹂有 萮る 海連

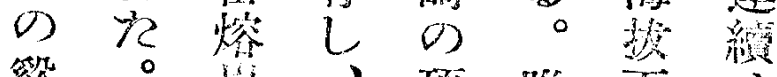

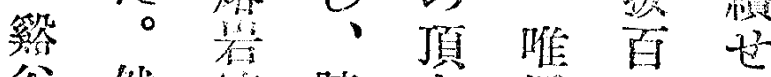
谷然策脇上辰予了

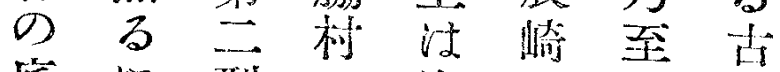

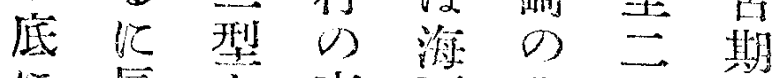

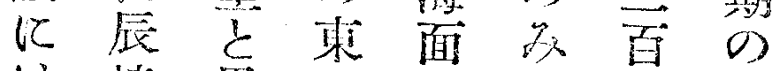

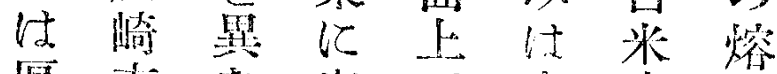

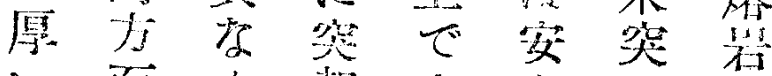

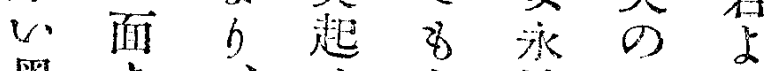

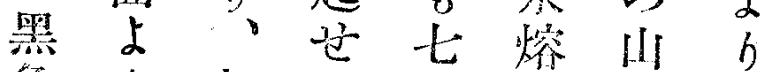
他却当十岩腹及

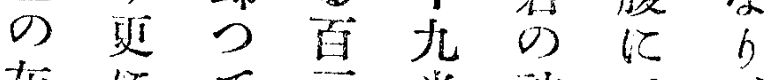

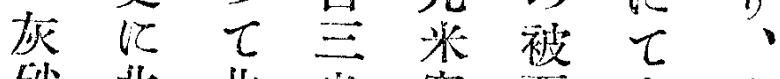

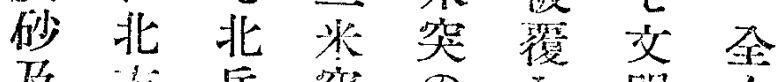

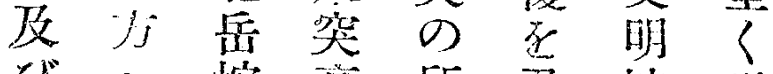
U゙ 人熔高所免熔仯 


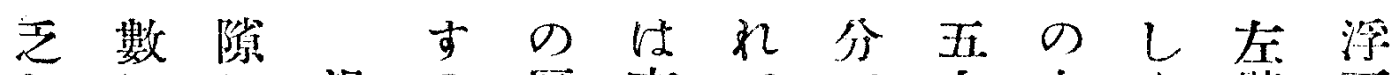
しにに湯の厚南てで十右た壁石

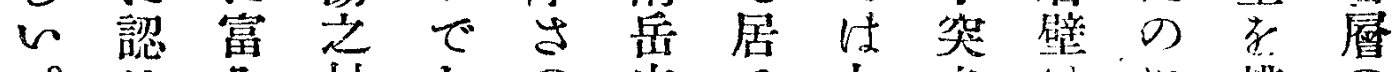

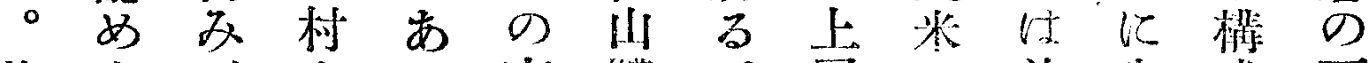

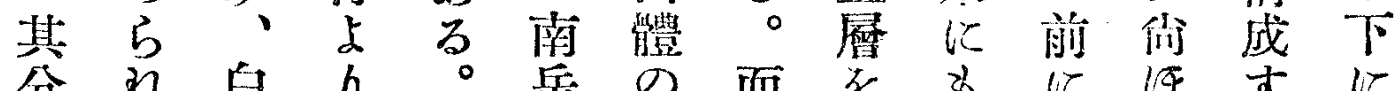

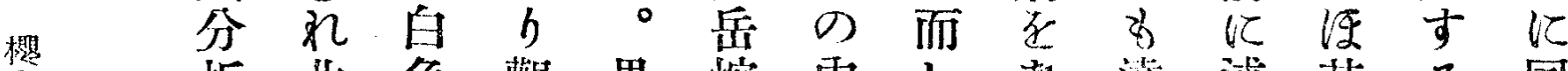

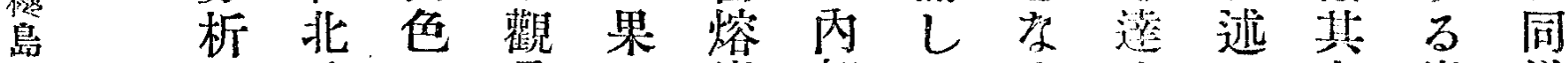

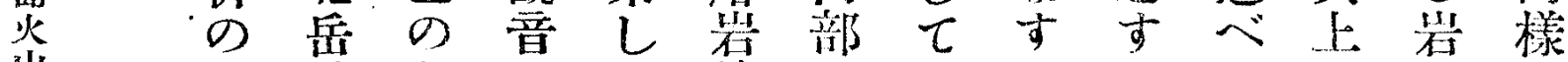
山 焒

結 熔·㸚 㥓

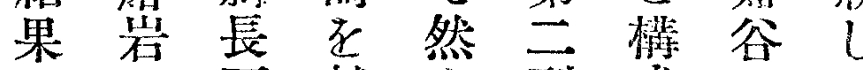

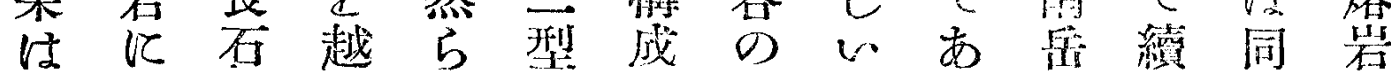
次甚がえばにし上熔ら熔い一の

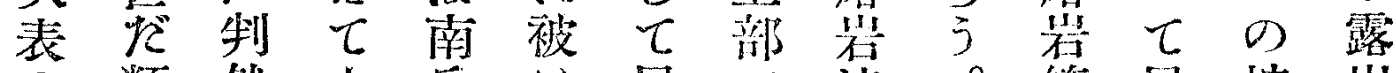
の類然古点恬居で流。渻居熔出

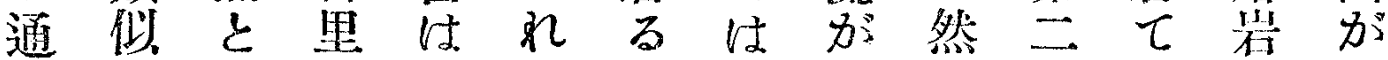

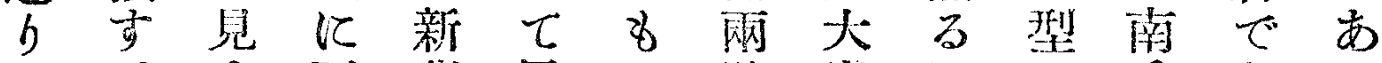
で。ゆ至蕉㕍の壁崩にで岳むる

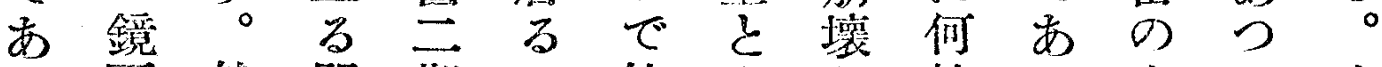
万下然間期の然古在故つ $111 \tau$ 留

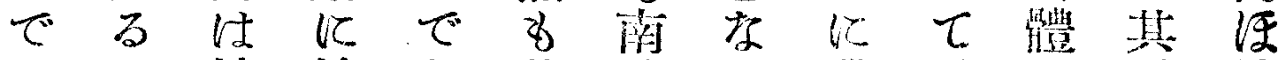
はに熔熔あ其岳し籍、落簬

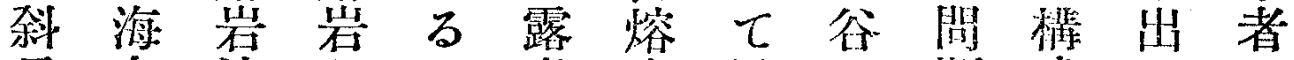

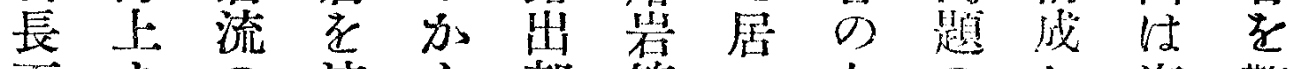
石よの 流 ら 部第 る

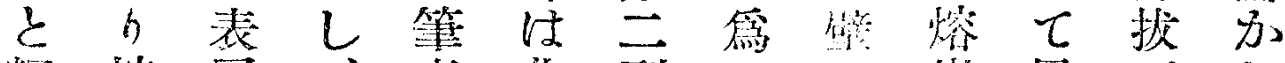
辉熔層、者北型的に罚居三し

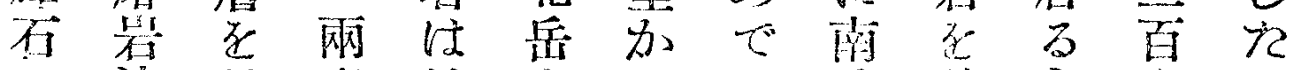
の流見者姑やら市茝被这米の

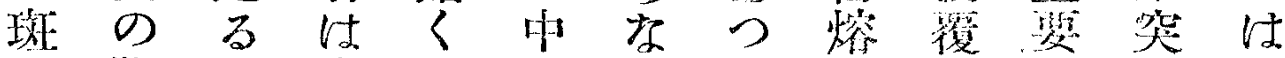

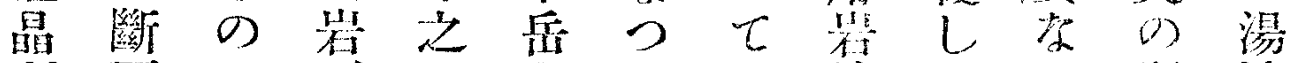

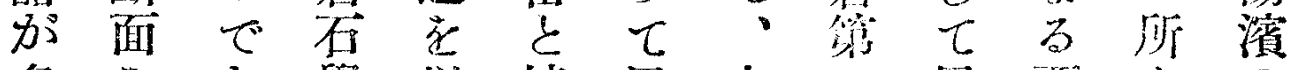

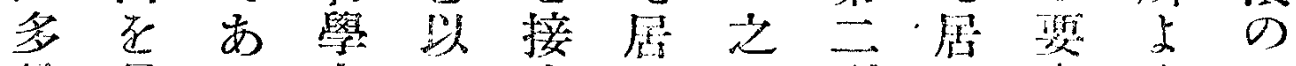

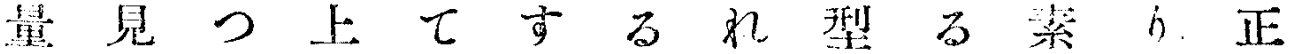

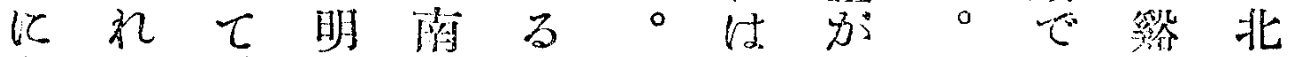

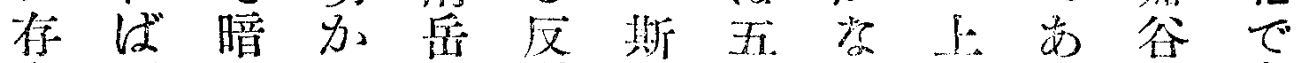

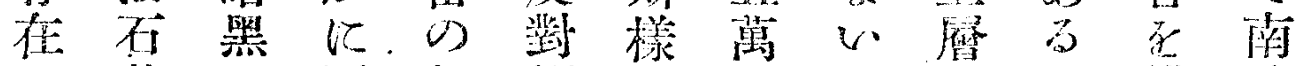

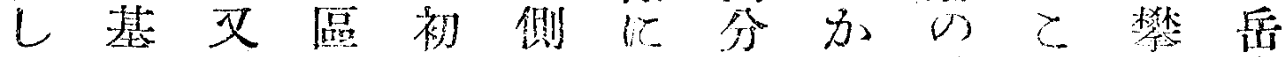

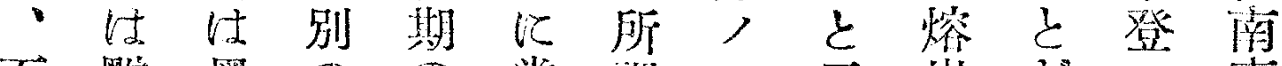

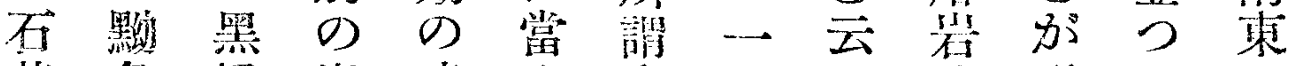

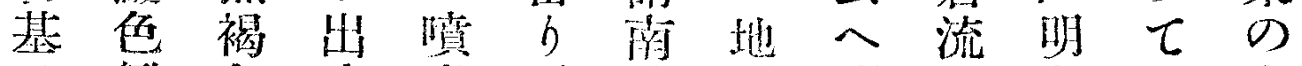
は緻色來出、盘形将壮と四山 三 朦

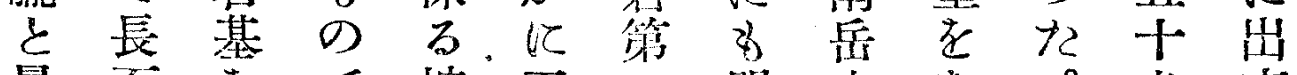

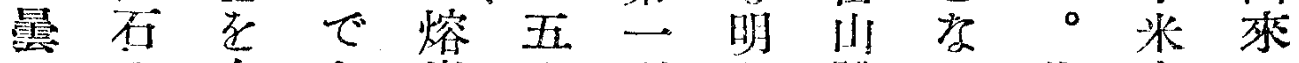

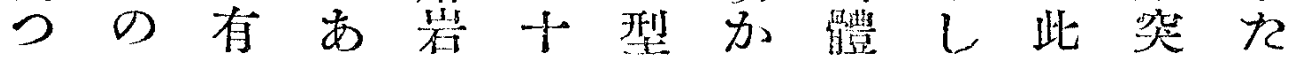

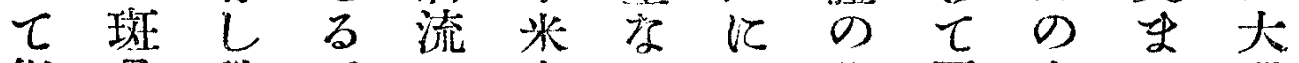
微晶稍。と突る表此厚大で籍

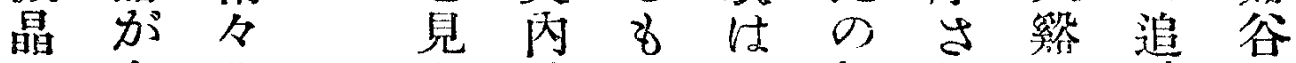
飞多孔做外の导部約谷跡の 
c 14 学㔔

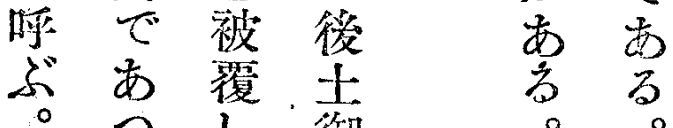

北 ᄂ 御

北 $\tau$ 元

西其居天

はの皇

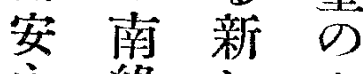

永緣 ᄂ 文

熔は的明

苼 黑 黑 墨

被酒瑰年

怯原 狀 b

丸の向

其北熔 七

の壁岩 年

境を流及

界京加び

は止公

海、の年

岸黑時汇

で种期亘

は小の

浦 b 姓

>浦出數

前, $飞$ 次

附前係 の

近にる.大

で至 合墳

あるの炏

万間でが

。沬ああ

大海 る

燃中。

崎に東北

の 突 北岳

遥入侧の

加 D 北

西九文東

方部明山

海 で 熔 腹

拔其岩它

百のは南

万先文岳

至端 明 の

云兌 三南

百大年 西

米燃の山

突 崎 噴 腹

五股金

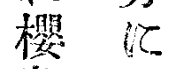

島

安 0

熔 $\tau$

明 岩 見

中求

螾にば

成 南

岩分岳

の 熔

似 岩

た第

8 =

の 型

老

求恃事部

め北實

(16)

(17) $(18)^{\circ}$ (19)

$\mathrm{SiO}$

61.51

1.12

60.47

60.26

$\mathrm{Al}_{2} \mathrm{O}$

16.28

1.83

2.23

1.19

4.91

4.99

5.72

2.65

2.81

2.98

$6.93 \quad 7.15$

6.70

3.21

3.21

$\mathrm{K}, \mathrm{O}$

1.42

1.41

1.33

$\mathrm{H}_{2} \mathrm{O}+0.05$

0.07

0.34

$\mathrm{H}_{2} \mathrm{O}-\quad 0.15$

$0.12 \quad 0.10$

.10

$\mathrm{TiO}_{2} \quad 0.64$

$0.6)$

0.75

0.19

0.18

$\mathrm{MnO} \quad 0.13$

0.11

$0.12 \quad 014$

万岳

な熔あ

5 喆

せ

分る載棈に四腹を

唯 b 分名世成露百南棈

大 8 析のれす出米東成

正著のとるる卞笑飞守

熔し結連る黟るすのある

岩々果續の色黑地る黟

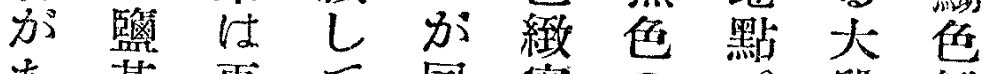

あ基更 $\tau$ 同密の筑緻

る性に居一の種谷密

許で確吕熔熔類左に

りあ蕒と岩宕。壁て

でつにと流

あて之恃で

る其を實あ

間 證 地つ

に據,の

制立踏 且

然七 查了

て〉で南

る 居 明岳

區る 为只

別の市

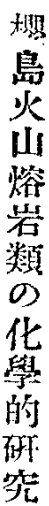

板

字 狀

す 笁

8 理 四

の

で有

唄

色方

緻 熔

密 岩 


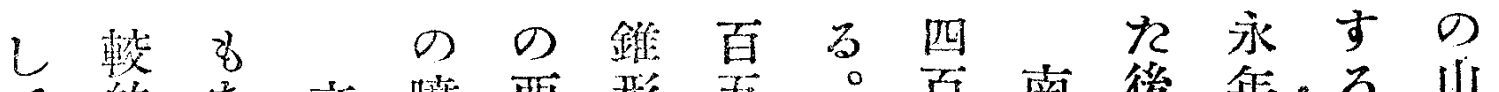

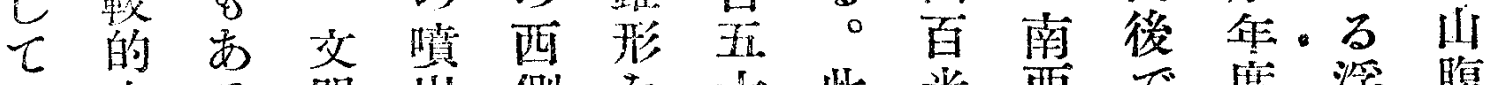
配少る 明出侧忞十此来西で度浮腹 列索。熔口面存米の笑侧あの石に

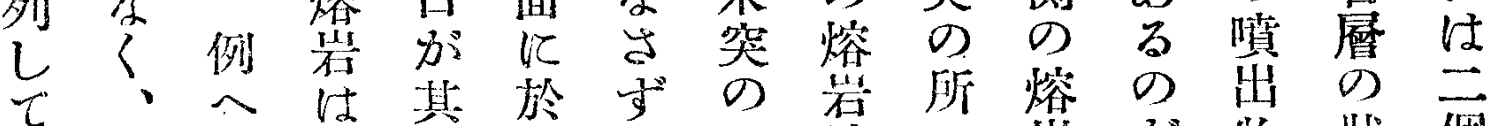

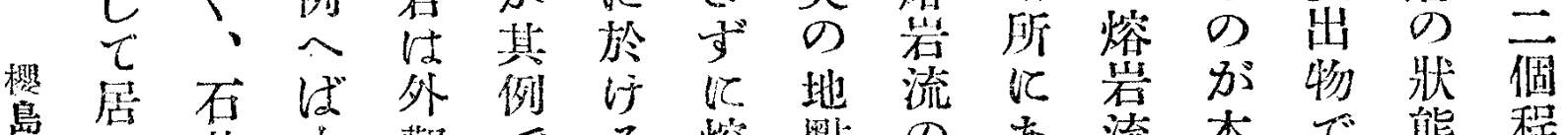
島る基大觀でる 熔點のあ流本で態程 III。燃黑あ サ宕よ地る灶あでの 熔岩奖崎色る

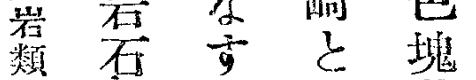
化诐黑 狀 學 矢 斑 神 で 的張中河妿 研 $b$ 原 永 筑複忙の泉 輝長北び 石石壁大 安 《正 山針 於熔 岩 狀け岩 で 万る

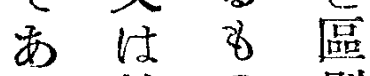
る摍 $の$ 別 。子 性 成水即難 分狀 5 。 壮兵。 炏微で併

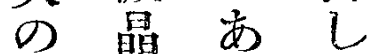
如度方熔 し び。 岩 輝镜流 石下の 、゙ 內 驖は部 政斜は の 辰 黟 微石色 晶の 緻 分斑 密

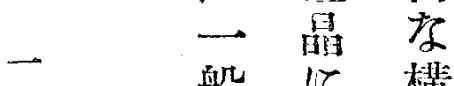

五般飞桠

飞比造

流 乙

狀輝有

棒石

造 類 万

存部

比分

ボ 2 大出

务桨导资

高 卒

地 镬

小 加

背亦

面

娄

市

小る

藤。

先

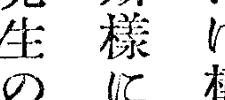

所爆遠

謂發谷

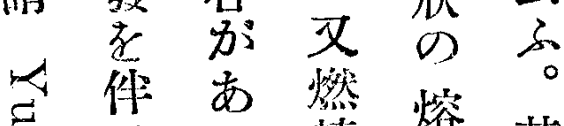

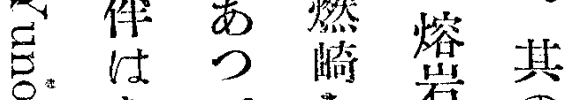

资てを石の

地等流最

噴形世流上

炎上海位

口區熔拔の

東大㚞别岩愎吕

微正市前

面喷る橥士南

几炎。竞粚

西の後下笑要

每著緣附南

第飞劣江西

三る吐接で师

期市出し步腹

熔つ孔て弓海

岩, て山海て拢 流彼圆拔居約
活てつ口

動突て 加

永、あ

通熔文 b

との熔之

ᄂ上岩 れ

てに站よ

居は大り

万斯 正上

汃樣 の 方

5 《垻は

で厚出安

物 永

浫の熔

石外岩

曆にに

加三被

学乐杜

居当

共厚网

れさ熔

熔の岩

岩古の

流以野

の 浮 外

叫石に

出 $儿$ 於

恃被訂

浮はる

石礼區

賴 $\tau$ 別

出居は

の る 其

盛。只

時之上

をれ泟

過は堆

ぎ 安 積 
煌此、゙附は熔て 岩の文に里齐活 は 外明 略と流動 黑海熔南湯出 の 色拔岩北濱 し 狀 塊四のにの況 牀百二並間。队 で来，部列に南 經

あ突をす 流 側 過

つと被る下で等

て百覆三しはに

镜米专個、海關

下笑了古拢的

の 附に火里二江

性近至口と百は

質につ爰米精

各各㐫崎乫识

交々。南之方々

明一此側の b知

丈個のの間七る

はと熔一の百と

大海岩 個 旗来文

正 岸 流学 学 加

の附の除はの出

熔近海け本間來

岩に中る熔にる八

二 飞他岩五。年

殆 個於分流個此

と文

區分る個 b 裂質

別認突の疗口炎忙

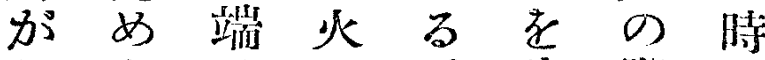

次至口。生際代

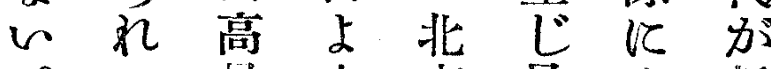

。る見b東最名新

唯・の多侧上南し

輝 東量で位岳心

石に文はの文

類當熔北火南け

中る岩岳口腹其

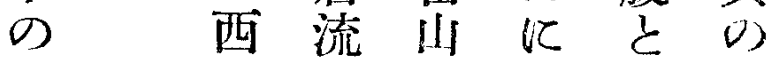

普迫を體よ北記

邂鼻姓の 万荝録

輝它海吐山出

石 あし拢出腹程

壮

紫

蕉

輝

\section{第 五表}

$(20)^{\bullet}(21)^{\bullet}(22)^{\circ}$

$\begin{array}{lllll}\mathrm{SiO}_{2} & 66.62 & 66.36 & 66.22 & 66.20\end{array}$

$\begin{array}{lllll}\mathrm{Al}_{2} \mathrm{O}_{3} & 15.33 & 15.05 & 15.22 & 14.89\end{array}$

$\begin{array}{lll}\mathrm{Fe}_{2} \mathrm{O}_{3} & 0.94 & 0.92\end{array}$

1.35

1.17

$\mathrm{FeO}$

$4.14 \quad 4.27$

3.99

4.18

$\mathrm{MgO}$

1.31

1.37

1.32

1.51

$\mathrm{CaO} \quad 5.00 \quad 5.21$

5.19

5.26

3.59

3.52

3.81

$\mathrm{K}_{2} \mathrm{O}$

1.77

1.74

1.84

1.90

$\mathrm{H}_{2} \mathrm{O}+\quad 0.15$

0.22

0.10

0.08

0.06

$\mathrm{H}_{2} \mathrm{O}-\quad 0.10$

0.14

0.30

0.72

$\mathrm{P}_{2} \mathrm{O}_{5}$

0.26

0.24

0.30

0.29

$0.11 \quad 0.09$

$0.11 \quad 0.09$

Total $\begin{array}{llll}99.95 & & \\ 99.78 & 99.89 & 100.10\end{array}$

䂟 $\overparen{23} \overparen{22} \overparen{21} \overparen{20}$

流

中四黑大揇燃

最種 部燃西㥓

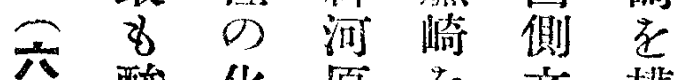

酸化原存文皘

性 學 $の$ 檴 明. 成

安 の成北成第 す

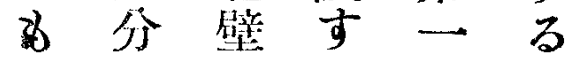

永の变る火黑

で比存嶂口色

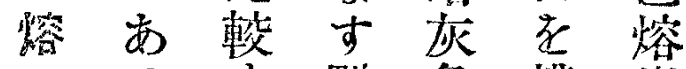

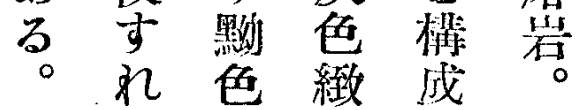

岩

ば繳 密す

相密のる

互 の 熔 黑

熔芣色

能岩。熔

類

似

全

鼠

D)

熔

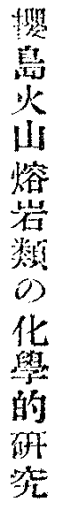


る一川發於落

。月 後最て大

次抹顶約近熔

に $に$ 上

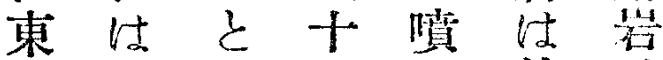

积 測其四火前は

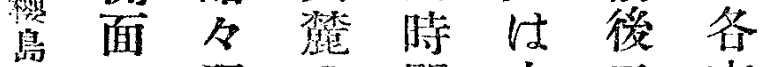

炎の現 の 間 大二方

山熔在線名正期 而

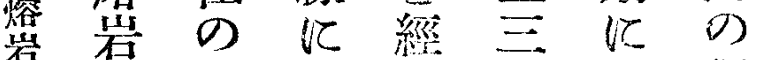

類流位淮て 年吐調

江置病斯一出查

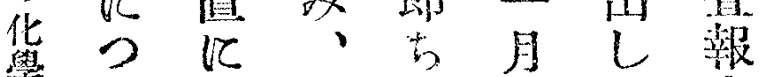

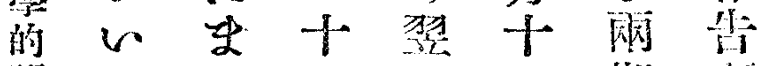

てで五け三期为

注進目日の多

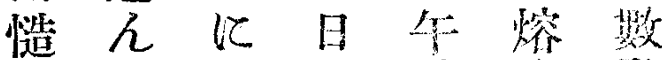

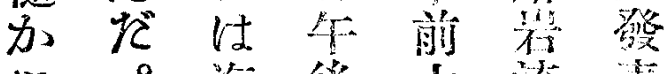

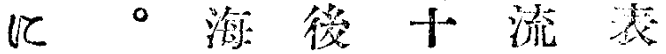

觀而最八時恃さ

测しに封束其れ

沬蓬前西化

ま熔 $乞$ 後兩學 居

け岩学们侧成る

れの。西面分方

ぞ吐超 側殆学ら

略出方面 ह゙異其

タ はてで同にに

同初十壮㭙す一

時め兵始にる般

にの旦め始票的

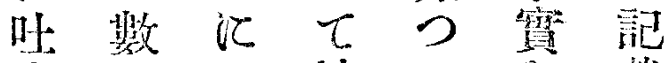

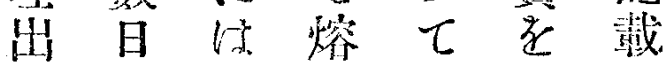

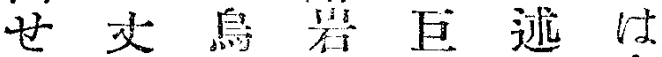

しで流量べ

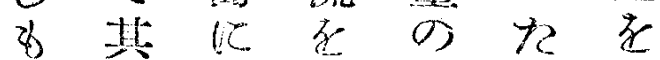

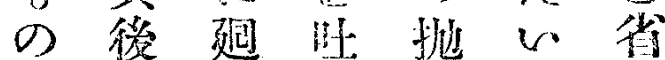

$>\sqrt{2} b$ 田田の䀩

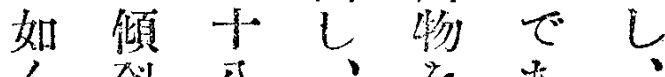

、唋公、学

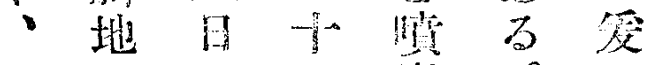

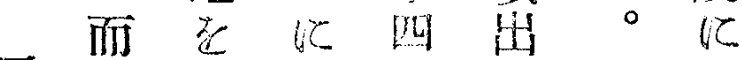

$\vec{t} し$ 流故日しは

$\tau$ 下鳟の视

$\rightarrow$ 宁

月它策で

の 手全匹 あ

末のくはる

にで顷䇥 か⿱

はあめ宕初
3

$\tau$

其

の

酸

E

度:

大 连

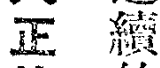

第 的

期 減

雀

路

3

の

壮

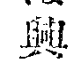

吸

票

万少㮴

青桨 0

暻く化

ᄂ

存 $九$ 战

け秒分

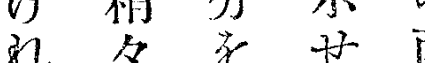

壮留有る活近

基 $ᄂ$ 基舅

5 性、如范熔

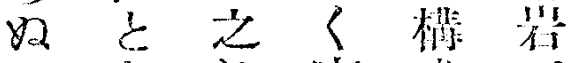

在和骨成

炎

期

湖

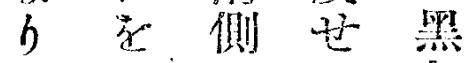

次交の万你

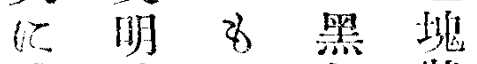

括熔の西狀

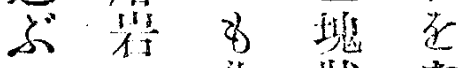

万比狀存

大此禁焀す

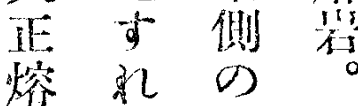

奀ばも

に球 $\sigma$

此酸 学

石

L

b

稍

8

多

v

漛

ic

㨘

齐

5

る

雨

储

面

)

焢

石

分

酸 辈

性各 
熔る䡛分

岩と的の

第 䛠 酸 根

二 叮 性 本

型 $ᄂ$ 七 的

のて あ差

成居つ趩

分 $5 \tau$ 七

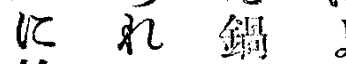

於る 政尚

$\tau \circ$ 方

第 斯 面 D

㞷禁当斿で

表禁斿等

10 因珫 ᄂ

1 に 熔て

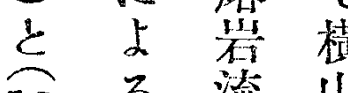

13 万 流

と第 内 古

は上部の

同の を

第 七表

䋊 以 氹

ᄂ 上

*(26) $(27)^{\bullet}(28) \cdot *(29) \cdot(30) \cdot$ t

$\begin{array}{llllll}\mathrm{SiO}_{2} & 62.15 & 61.30 & 61.25 & 60.59 & 60.58\end{array}$

$\begin{array}{llllll}\mathrm{Al}_{2} \mathrm{O}_{3} & 17.35 & 16.56 & 16.68 & 17.87 & 17.10\end{array}$

8 所

$\begin{array}{llllll}\mathrm{Fe}_{2} \mathrm{O}_{3} & 1.49 & 1.73 & 1.33 & 1.22 & 2.33\end{array}$

の 謂 海:

$\begin{array}{llllll}\mathrm{FeO} & 4.69 & 4.99 & 5.19 & 5.59 & 4.40\end{array}$

$\begin{array}{llllll}\mathrm{MgO} & 2.17 & 2.43 & 2.65 & 2.39 & 2.57\end{array}$

$\begin{array}{lllllll}\mathrm{CaO} & 6.05 & 6.44 & 6.25 & 6.34 & 6.61\end{array}$

$\mathrm{Na}_{2} \mathrm{O}$

$\begin{array}{llllll}2.72 & 3.41 & 3.25 & 3.04 & 3.26\end{array}$

$\mathrm{K}_{2} \mathrm{O}$

$\begin{array}{lllll}1.56 & 1.40 & 1.53 & 1.68 & 1.61\end{array}$

$\mathrm{H}_{2} \mathrm{O}+$

$\begin{array}{llllll}0.63 & 0.46 & 0.47 & 0.59 & 0.49\end{array}$

$\mathrm{H}_{2} \mathrm{O}-$

$-\quad 0.12 \quad 0.05$

0.12

$\mathrm{TiO}_{2}$

$\begin{array}{lllll}0.65 & 0.70 & 0.73 & 0.71 & 0.51\end{array}$

$\mathrm{P}_{2} \mathrm{O}_{5}$

$\begin{array}{lllll}0.12 & 0.20 & 0.29 & 0.08 & 0.24\end{array}$

$\begin{array}{lllllll}\mathrm{MnO} & 0.17 & 0.11 & 0.68 & 0.24 & 0.09\end{array}$

$\mathrm{SO}_{3}$

0.18

0.23

で 第 陝

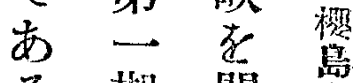

当期 閉

の 塞

山

成 熔 ᄂ 岩

分宕、類

は流有句

次で材儌

のあ㤎的

如 つ面研

Total $\quad \begin{array}{lllll}100.48 & 99.73 & 99.70 & 100.47 & 99.7 y\end{array}$

地變占

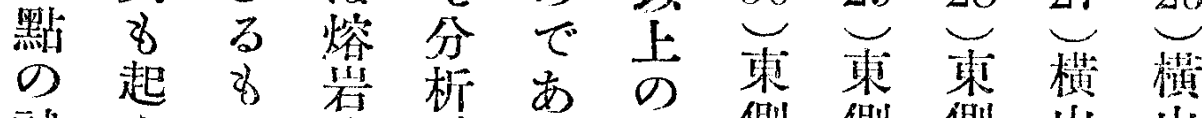

試 らの 流試つ分侧侧侧山㠼

料得での 料七析面面面淈方

でる結表る 前表䥀鍋瀨上面

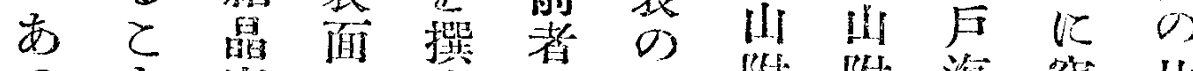

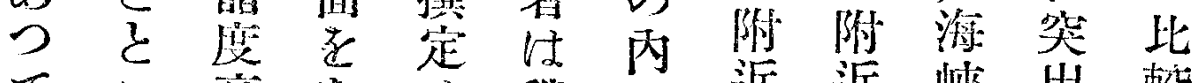

て〕高学せ稍 26 近近陝出較

表思〈世蚂

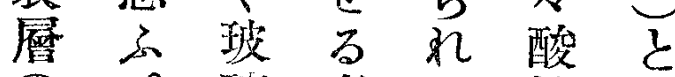

の。璃 者し性 29

10 例 にで倍 で 29

10 无結 藤 後

はばし晶教者は

結箐人度授性

昆者隨低は秒留

度 の $\tau<$ 々

低調此玻㣗覧香

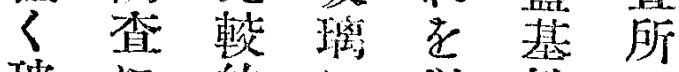

玻に的に性

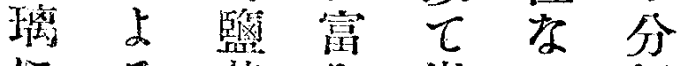

にる基み岩る析

富と性隨漿事江

ん献でての實係

で岳あ比成にる

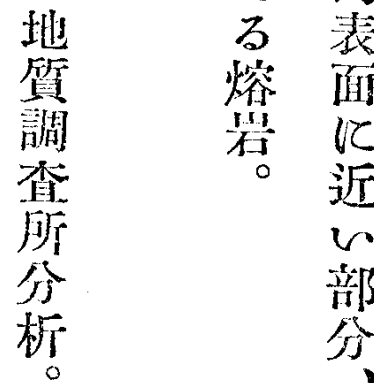

て で

其

吐大

出醉

は の

急 戶

激 赫

で舅

あ

כ b

抎西

多 $y_{j}$

政 你

日 引

v $v$

L 72

て 線

其 加 $^{3}$

椨 海

获 面

杜上

步 $\sqrt{ }$

近市

流 签

下岩

地留哲流

月 前

稳旬面

所市市

析

でつ

大 72 
2 出

長 る 其 身

期 儿事 侧

化至 1 鍋

亘 つ終 川

樻つた熄 方

島七值

火流第たで

胳出 $-の \sqrt{2}$

岩し期で—

彩れ熔あ月

化點㞸方年

綮古の 品

呴前姓其日

研者出後の

注再 多

墨急 び方

原激第比流

るで 正算

市 期 -

此了熔期

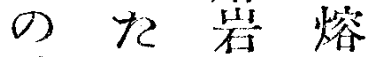

熔范葆

碞又徐学

流其名初

加期 $v め$

始間流て

女 多出 嗢

$\tau$ 短 し 出

吐为化

出了前 一

しつ者月

れ少来

のの 表 日

は に面に

何反のは

日 ᄂ大遂

頃て 部に

少第 分 瀨

正三学 戶

確 期 被 旗

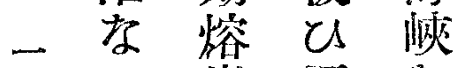

九る岩更索

觀 は に 閉

察 極 海 塞

者く上し

加 徐 遠 熔

学々岩

いで管の

$の$ 且出跇
ら山け飞水酸れのる緢

ういる西準性ば試の分 か 各㒋ので東料で酸 。火面高 あ 侧はあ性 此口でいるる面稍るで

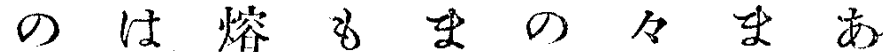

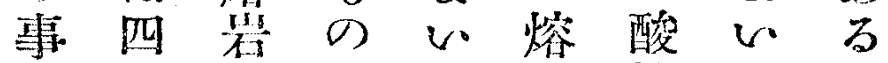
纴百流程各岩 性各口

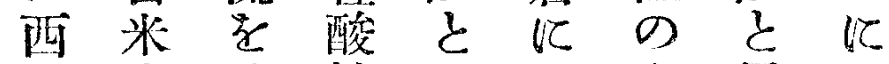

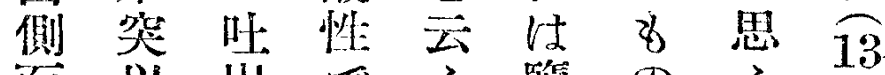

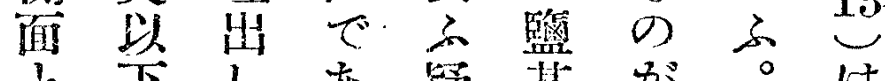
と下しあ疑基㤎。は 東のれつ范性多僧其 侧高永て 抱のくし内

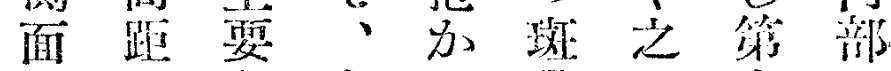
の口次之し晶に学 熔子当和加反表占

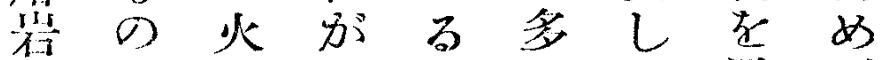
流で门低市心元逝石 にあはくのと柬臨其

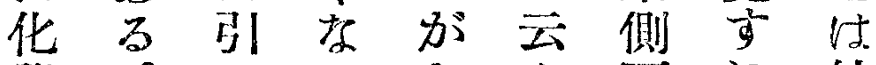
學。弓る る及面れ絬 成さ本程るとのば晶

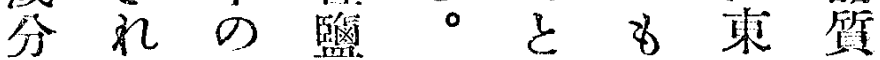
上ば北基八での西文 の本東性ワあ洁爾な 差. 火灭に 異师當存の方的面稍 市でるる尚ら其㣻

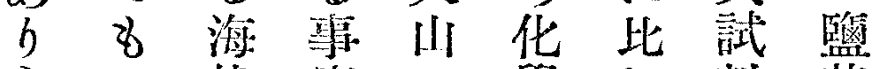
队 八拔實で學し料基

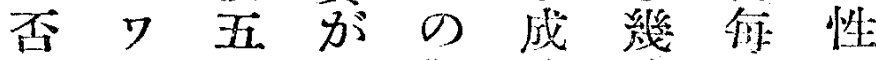
や1百あ觀分分にで

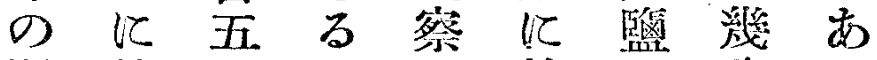
開於十と於基尔る 題け米云上て性上の

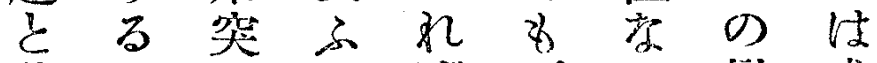
共との。ば可る變或 飞问地今新侧加鲁は

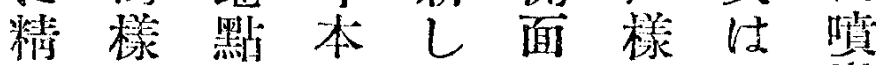

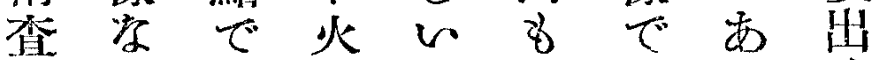
勆事师熔のあ後 要璂るに芣は尚どに 寸加の就流東。如斑 ベあにて は 侧小何晶 さる東之其面藤にの

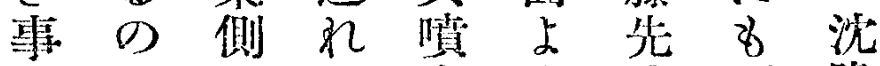
項で面范出 h生西降 であに見口秒に側に ある於るの各よ面因 
十の大居で㲏熔ししを通ので

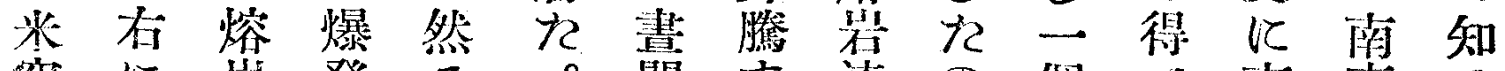

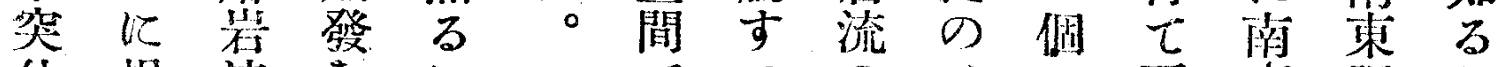
位揭流をにでるの注の再整隅索

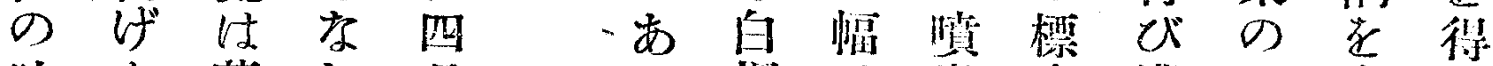

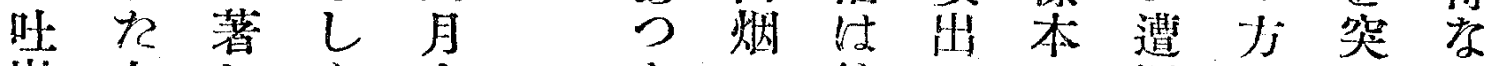

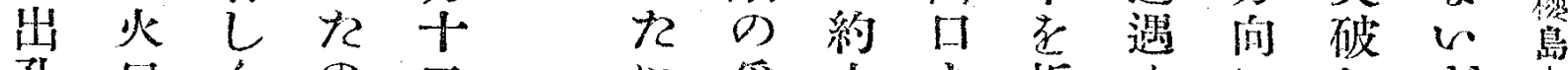

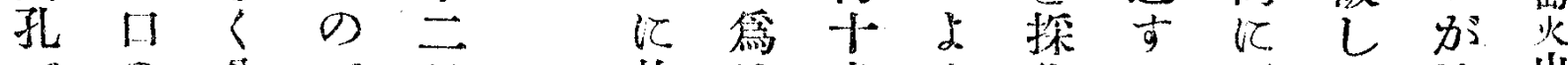
での分で百 亦外星接鼠 る『底び 第增加同 此三乙出地 の 期火桃在

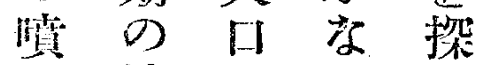
孔熔は少檢 注倠其口世 熔苂本え 宕吐ば。主 是出此乞 出し之のれ 乙九爆封 次埋發比 㕛川死 で加 5 间 前 爆令年回 發一七九消济 をつ居月穏 作あ萑南

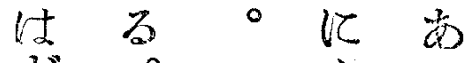
प” है 0 爆关一元 發等日 は壮數 川 其踢包分 值 II 起 爆 上倘 つ 發

に侧 た 性

あ の 等と

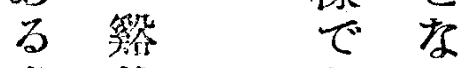

火谷要

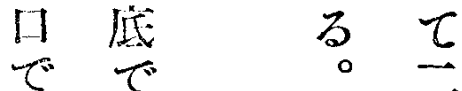

起要四時

つつ月間

元中每

以堡旬飞

上直任烈

三德此沱

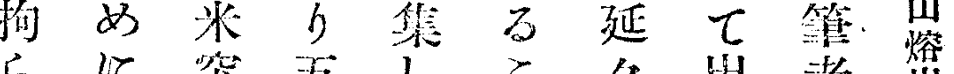

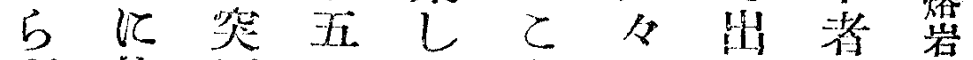

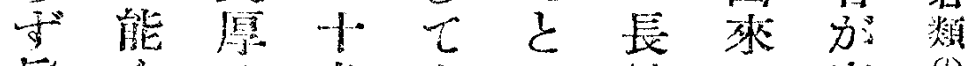

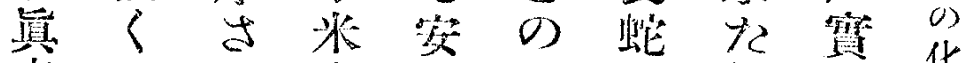
浾的三突全出の新地华

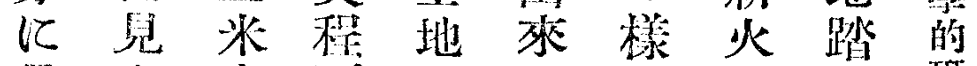

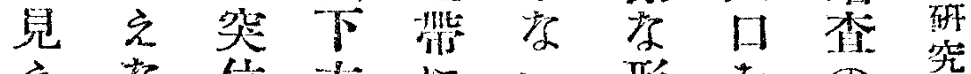
え拉位江心形范觉

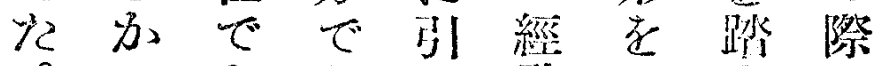

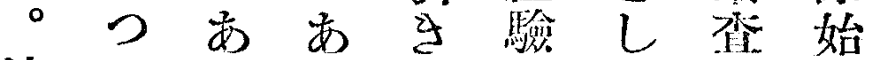

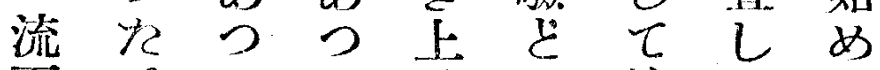

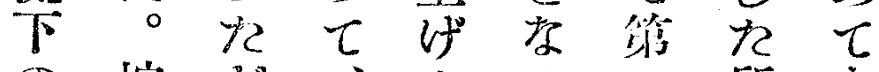
の熔分、范口所芝

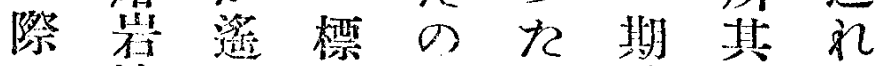
流流本での熔火に

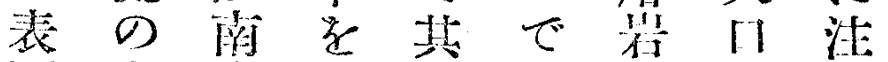
面表東探觀あ心底意 の面を背察る 略のし

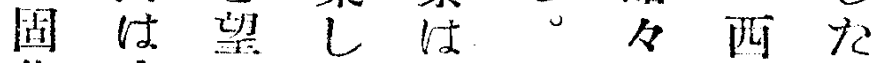

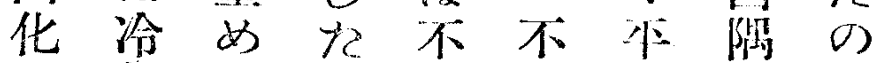
せ却ば纺正睆坦よは

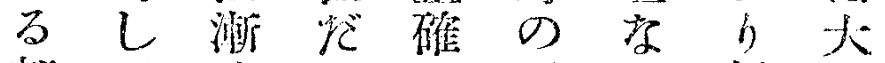
部 て头出で爆る新正 分黑幅らは發衣九哀

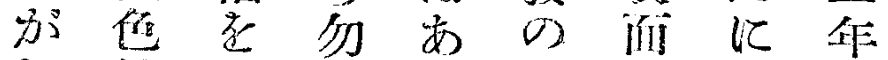

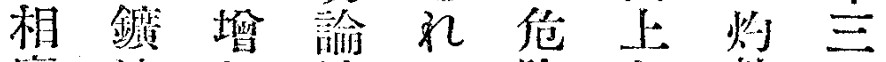

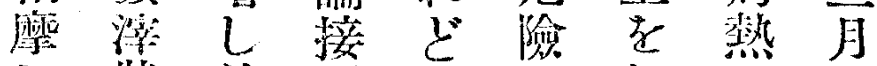
乙 狀前近、加世抑世 てを面方笛要出る三

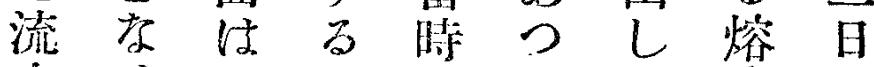
水世一乙のた岩で のど屏手手の居吕あ 如其措分記でる現つ

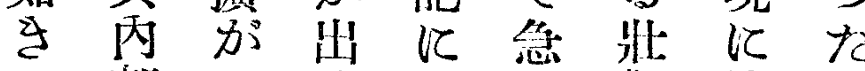

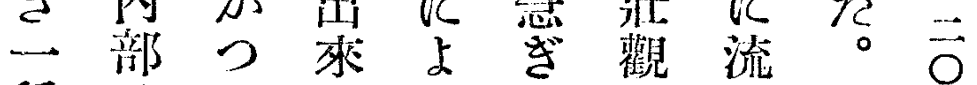
種注て没此出常 の灼る。ばの目し昌 畐熱樣此筆光罊つ鍋 を世での者景すう们

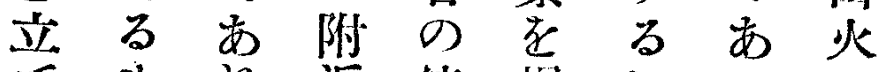

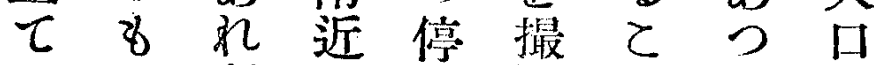
১のどの歨影と壁 


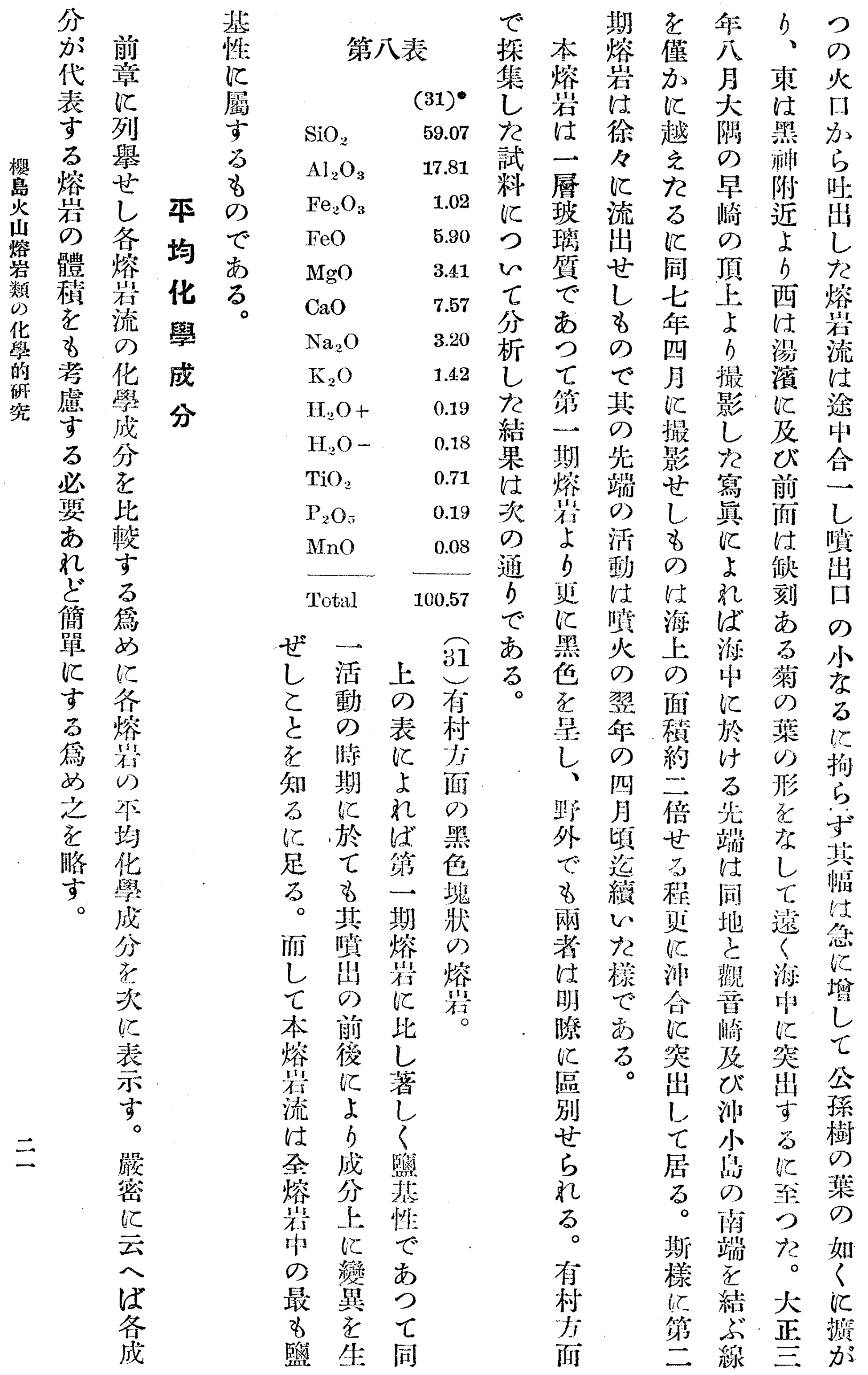




\section{第 九 表}

三四三要昰无元

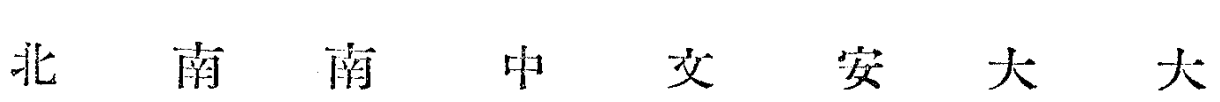

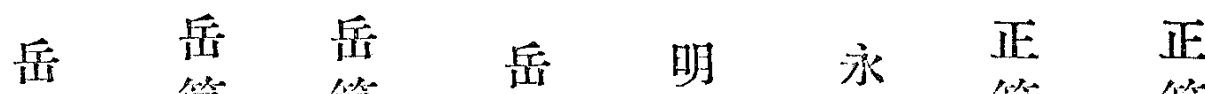
熔 $\quad$ 二 第

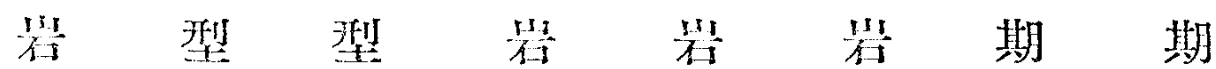

\begin{tabular}{|c|c|c|c|c|c|c|c|c|}
\hline $\mathrm{SiO}_{2}$ & 64.59 & 60.87 & 64.00 & 63.97 & 66.35 & 64.52 & 61.17 & 59.07 \\
\hline $\mathrm{Al}_{2} \mathrm{O}_{3}$ & 15.96 & 16.38 & 15.85 & 15.62 & 15.12 & 15.05 & 17.09 & $\mathbf{1 7 . 8 1}$ \\
\hline $\mathrm{Fe}_{2} \mathrm{O}_{3}$ & 1.85 & 1.72 & 1.76 & 3.09 & 1.10 & 1.77 & 1.62 & 1.02 \\
\hline $\mathrm{FeO}$ & 3.96 & 5.29 & 4.33 & 3.35 & 4.15 & 4.68 & 4.97 & 5.90 \\
\hline $\mathrm{MgO}$ & 1.90 & 2.86 & 1.68 & 1.85 & 1.38 & 1.72 & 2.44 & 3.41 \\
\hline $\mathrm{CaO}$ & 5.74 & 7.05 & 6.22 & 6.04 & 5.17 & 5.55 & 6.84 & 7.57 \\
\hline $\mathrm{Na}, \mathrm{O}$ & 3.23 & 3.26 & 3.60 & 3.22 & 3.62 & 3.87 & 3.14 & 3.20 \\
\hline $\mathrm{K} . \mathrm{O}$ & 1.69 & 1.42 & 1.59 & 1.61 & 1.81 & 1.70 & 1.56 & 1.42 \\
\hline $\mathrm{H}_{23} \mathrm{O}+$ & 0.41 & 0.78 & 0.17 & 0.22 & 0.14 & 0.08 & 0.53 & 0.19 \\
\hline $\mathrm{H}_{2} \mathrm{O}-$ & 0.19 & 0.14 & 0.13 & 0.23 & 0.15 & 0.11 & 0.10 & 0.18 \\
\hline $\mathrm{TiO}_{2}$ & 0.59 & 0.66 & 0.65 & 0.75 & 0.74 & 0.77 & 0.66 & 0.71 \\
\hline $\mathrm{P}_{2} \mathrm{O}_{5}$ & 0.25 & 0.20 & 0.16 & 0.36 & 0.27 & 0.22 & 0.19 & 0.19 \\
\hline $\mathrm{MnO}$ & 0.16 & 0.13 & 0.09 & 0.14 & 0.10 & 0.12 & 0.14 & 0.03 \\
\hline $\mathrm{SO}_{3}$ & - & 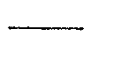 & - & - & - & - & 0.21 & $\omega$ \\
\hline Total & 100.33 & 100.02 & 100.10 & 100.25 & 93.95 & 100.05 & 100.06 & 100.57 \\
\hline
\end{tabular}

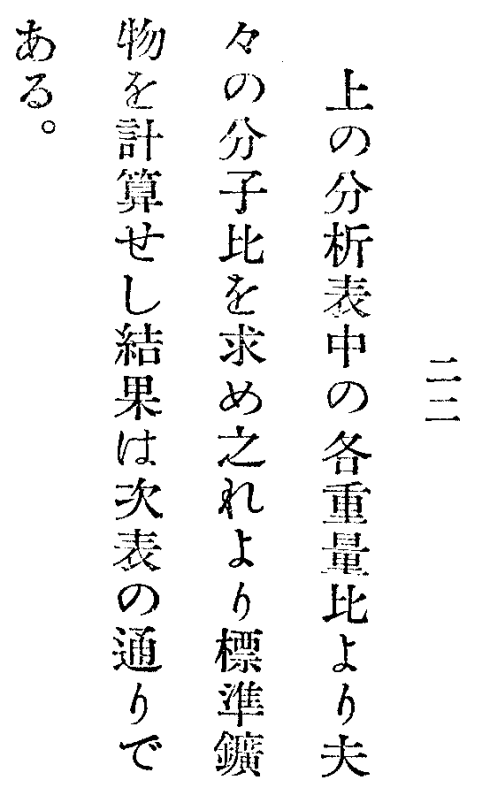


籍

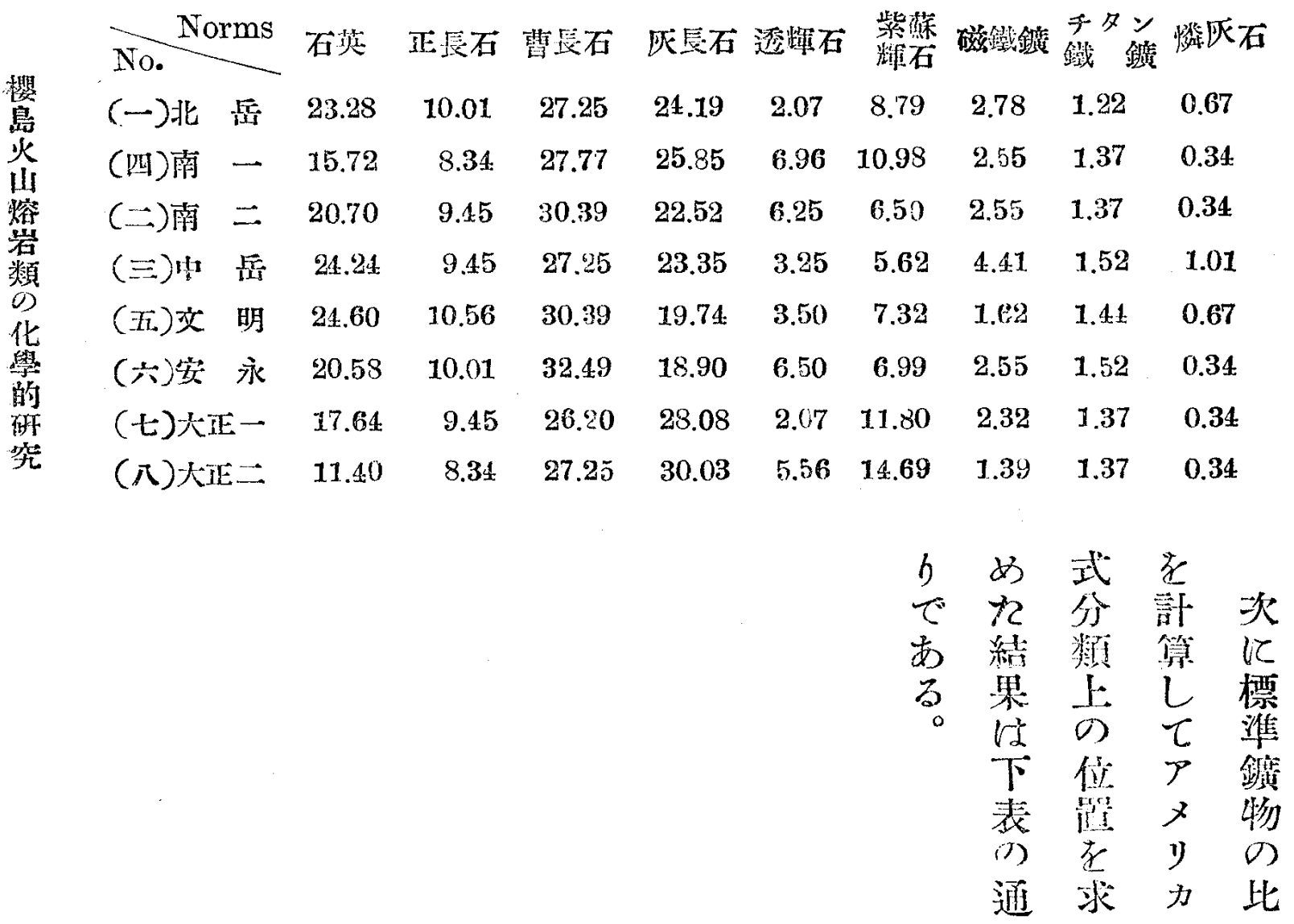

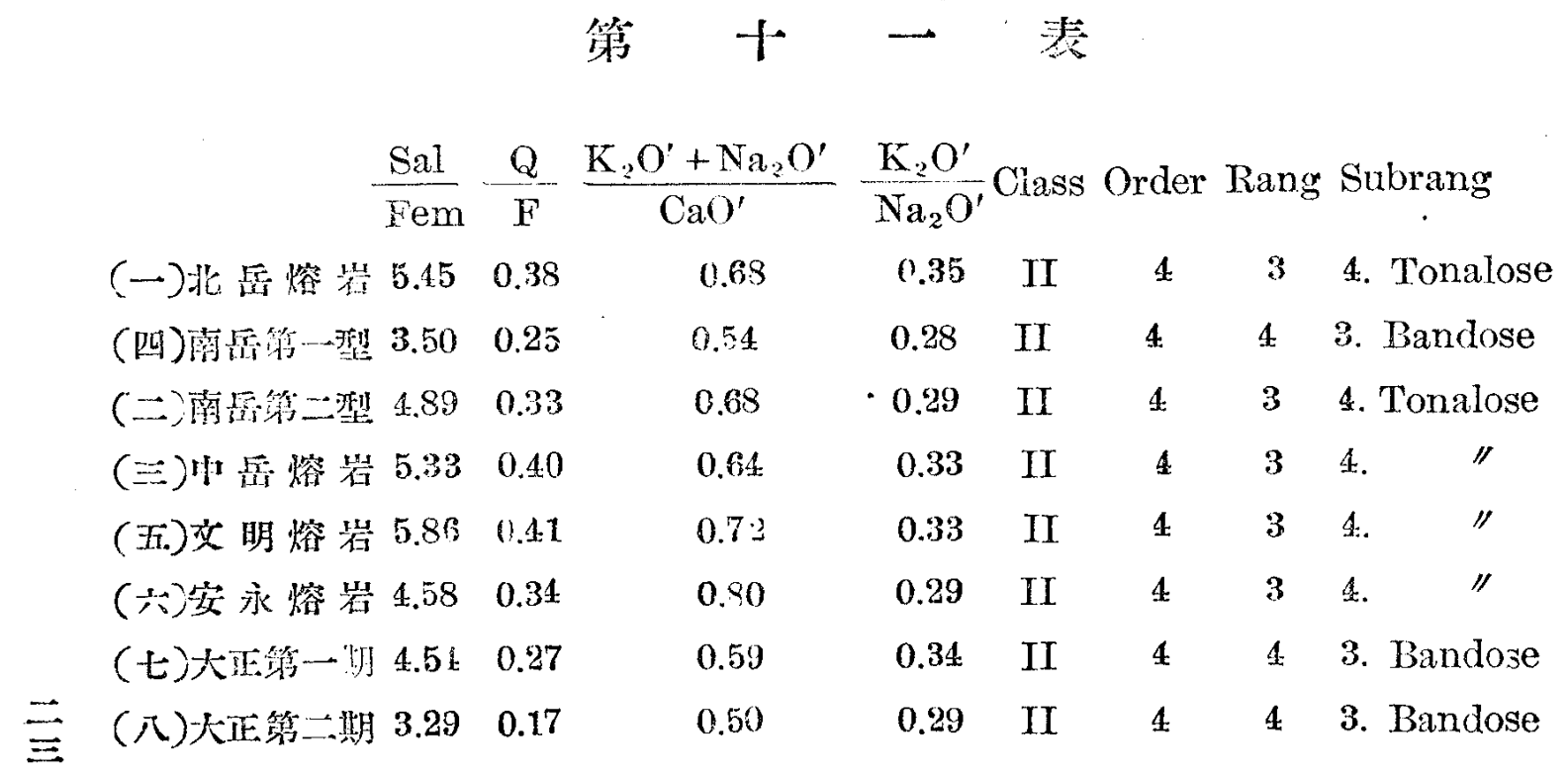




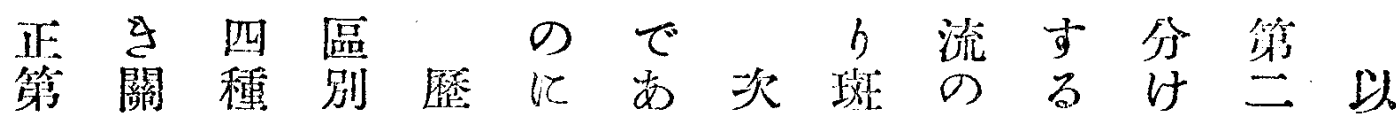

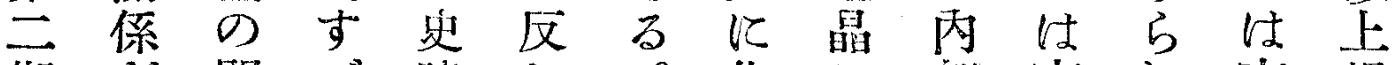
期吕間 ベ時 し。化这部南我南揭 熔あに鸟代て 北學制を岳斑岳げ 岩つ活邀の南岳成然占熔晶型し

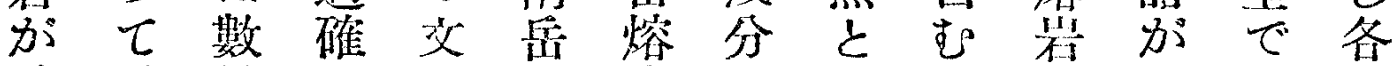
最、量质明三罗に見る第大古焀

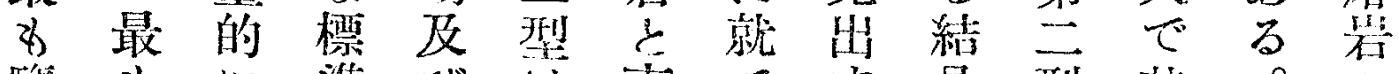

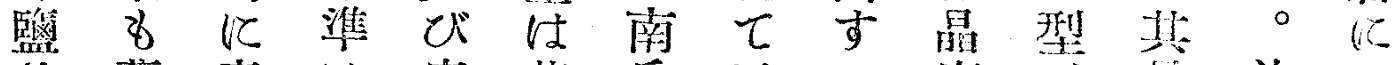

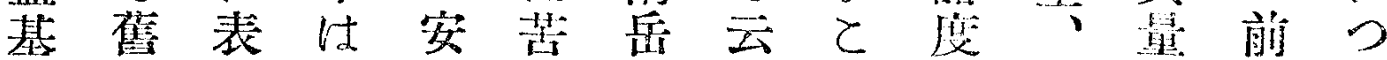

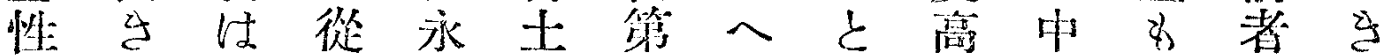

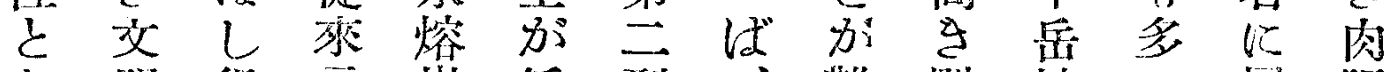

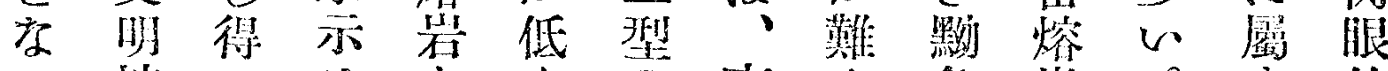

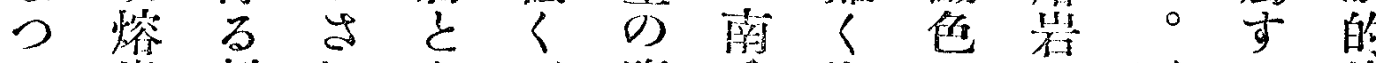

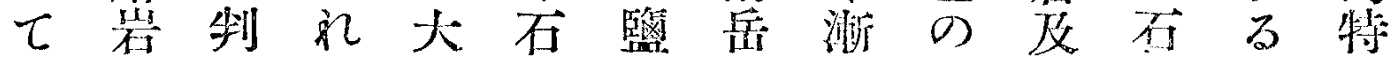
居 加然 $\tau$ 正灰基熔く種び基洁徴

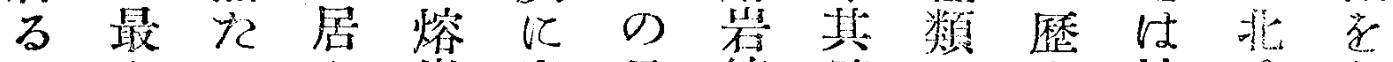

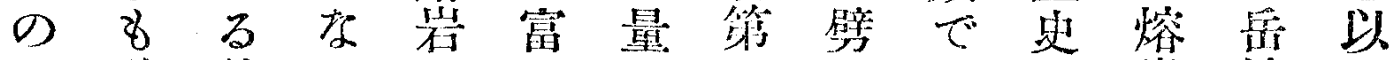

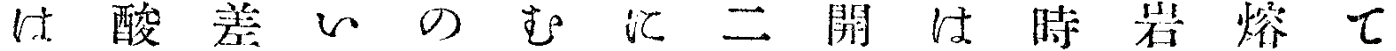

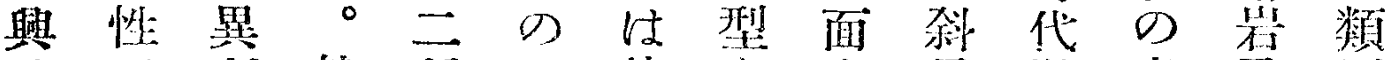

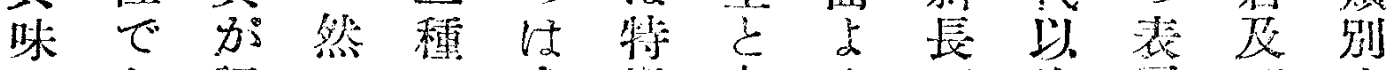
ああ認ると成徵中方不後虔びす

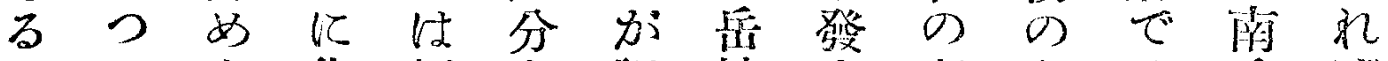
乙てら 化極上認烇す斑各は洍ば

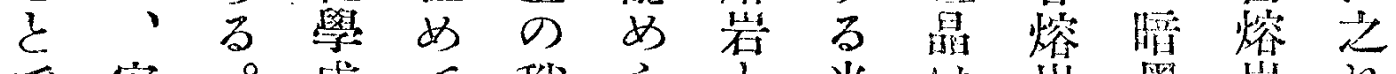

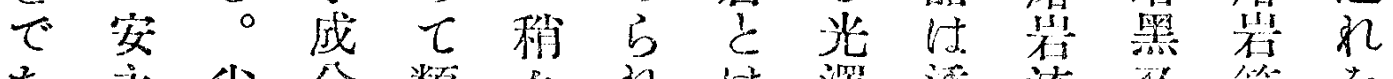

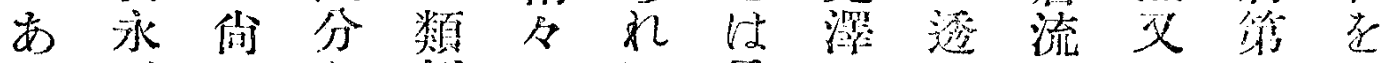

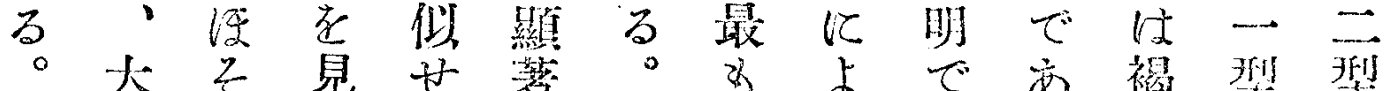
正の犯る浆即類つ比つ黑でに

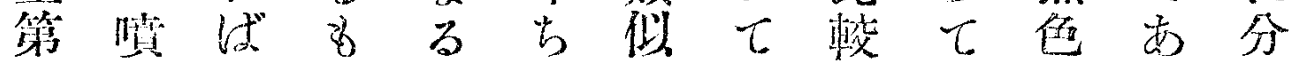
一出各の區北し存的一花つつ

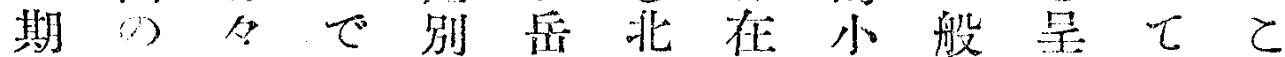

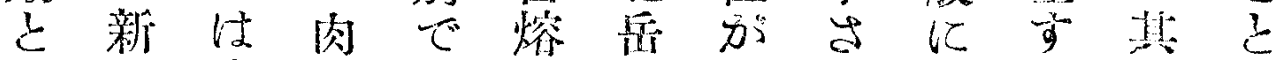

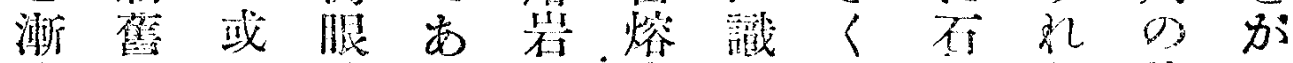

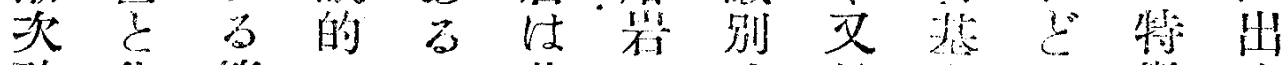

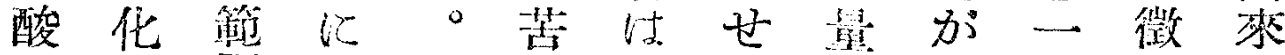

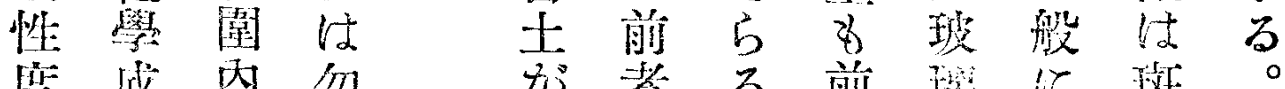

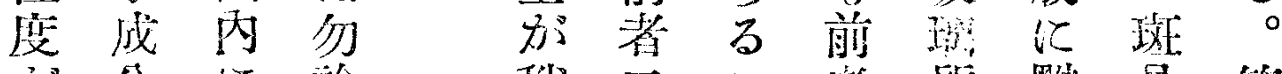

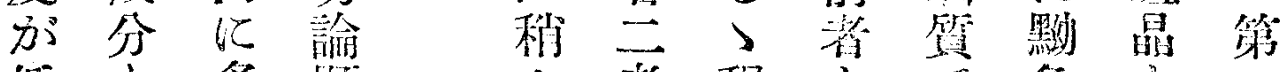

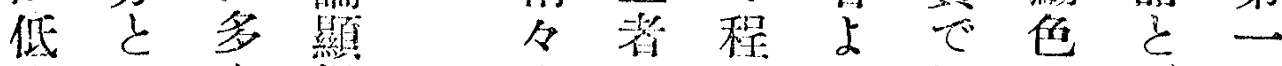

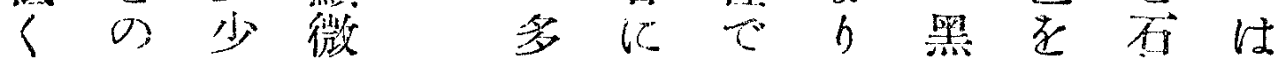

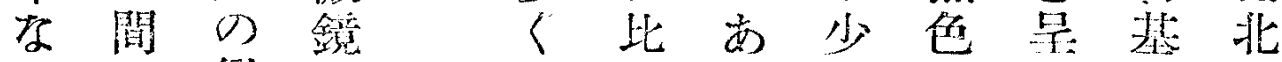

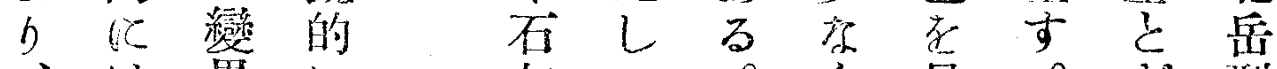
、暴に灰—型

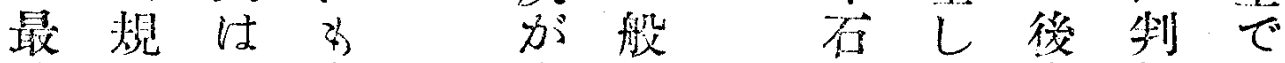
後則西劣少に基、者然汸

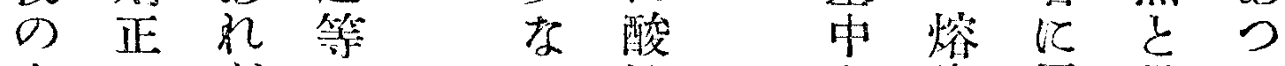

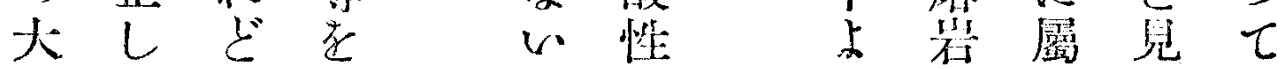




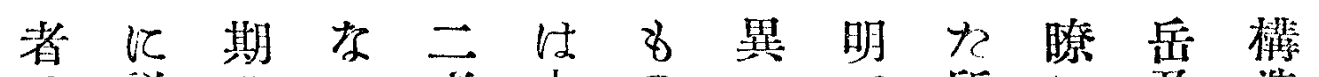

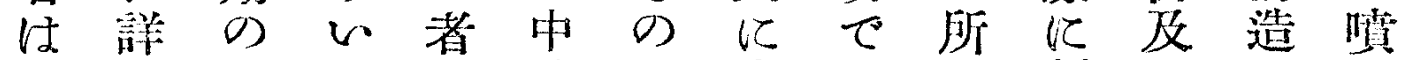

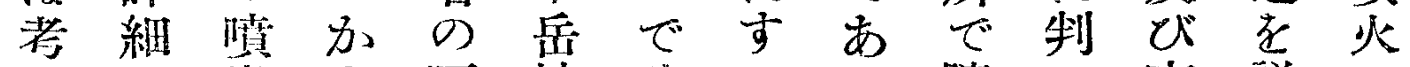

人に出ら下熔殊るつ隨つ南詳の

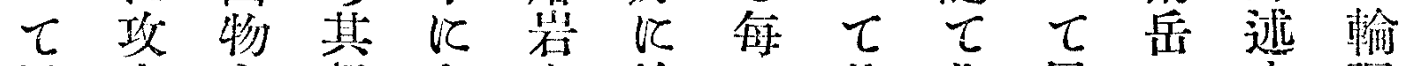

居究と新 あと第に其北居の邀

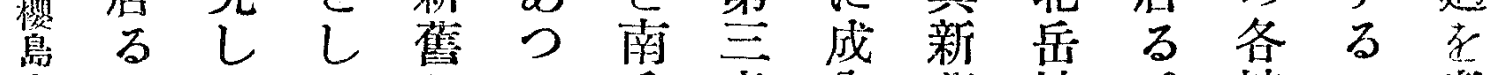

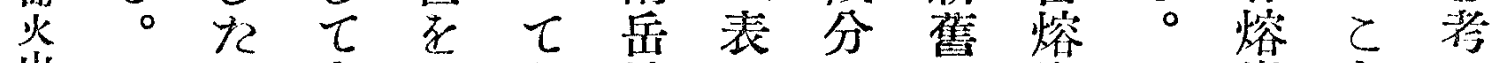

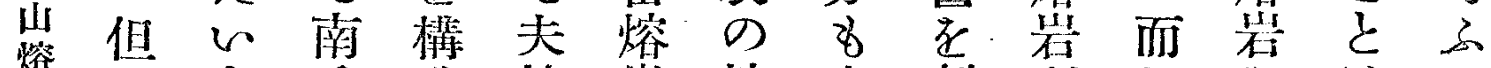
岩しと岳造等碞 熔亦制分し学は方 類同思熔の上符罟 舅 定右七第笼に

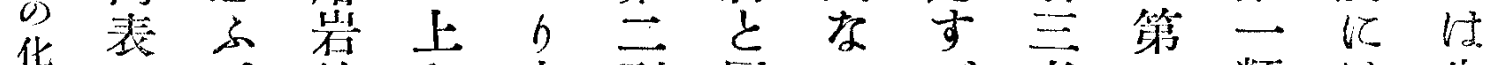
倏の。第另古型同るべ者一類注光

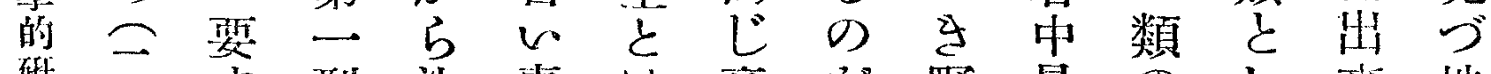

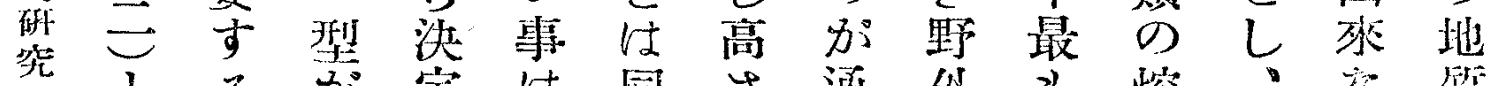

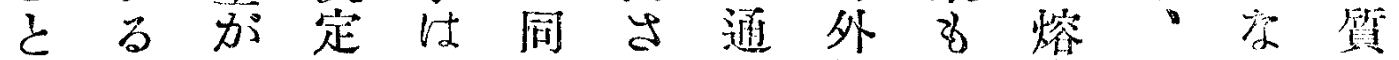

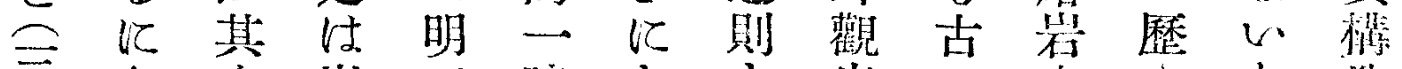

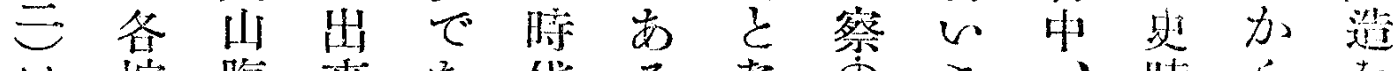

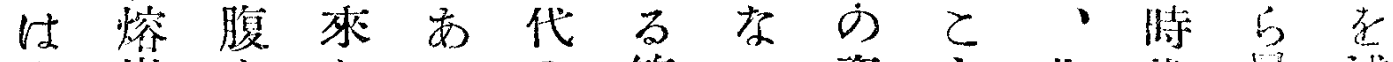

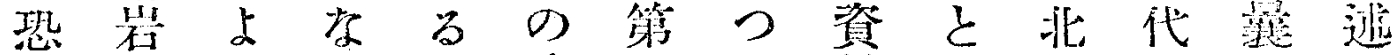

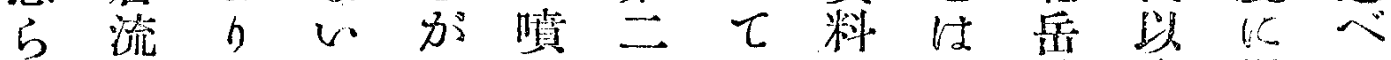

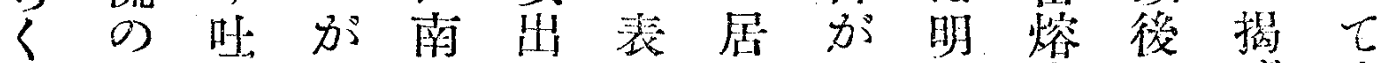

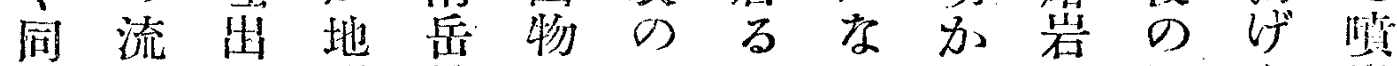
時出し 形第で 9 の 代しれ上一正

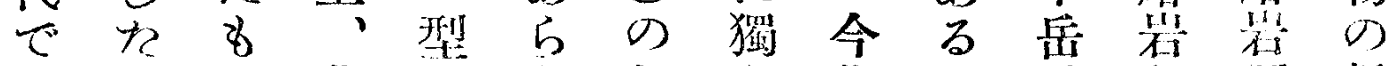

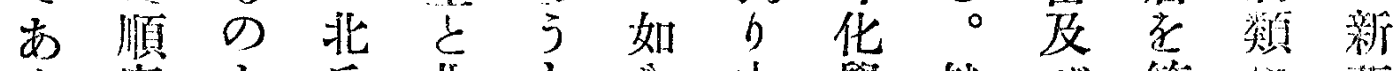

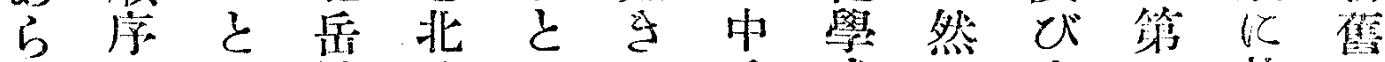
うは思熔岳想㤌岳成る 南三就の

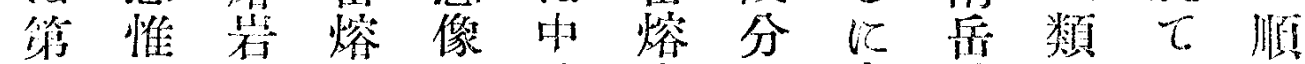

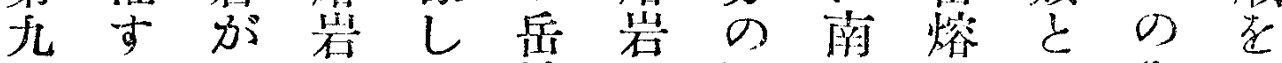

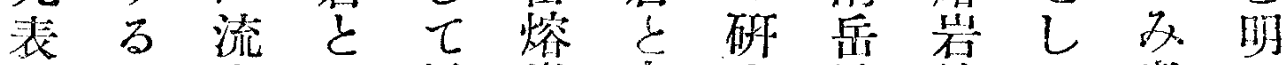

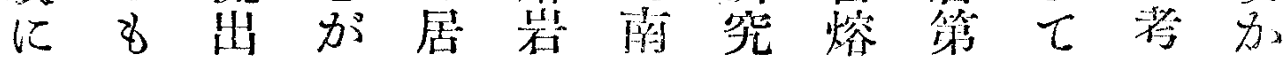

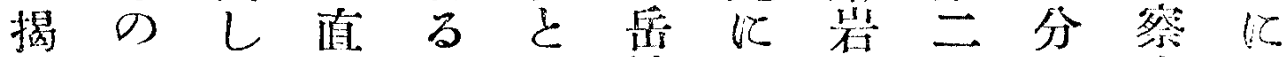
げでて 接 の 殆 熔 就第 型て 等し

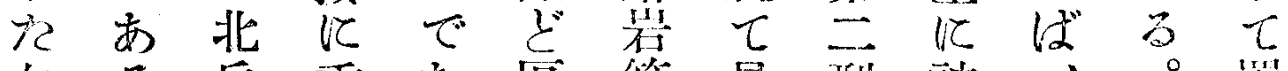
左る岳重市區第見型被・洸。 侧。近る別三る亡復後符か

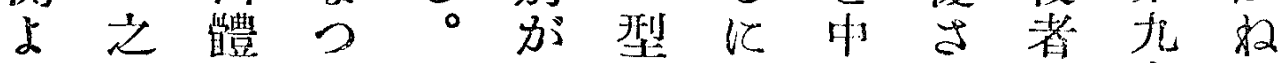

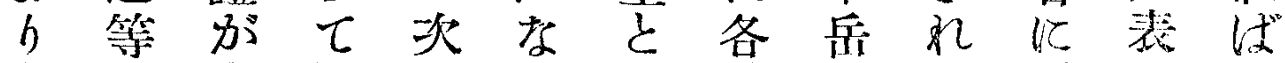

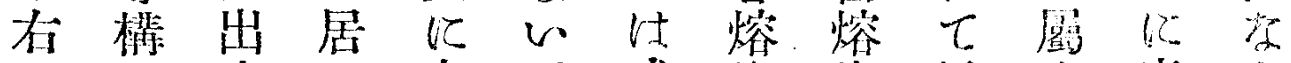

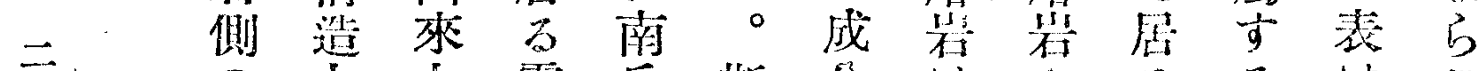

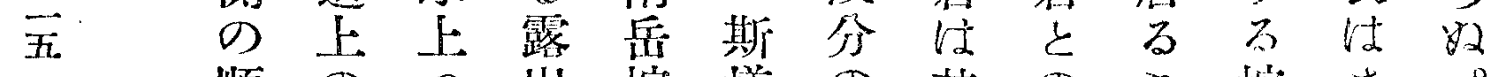
順のつ出熔㯟の 其のと焀さ。

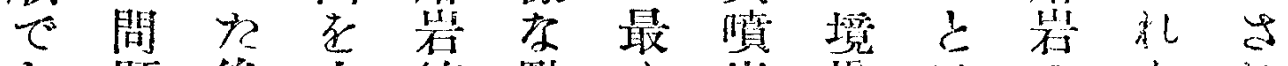

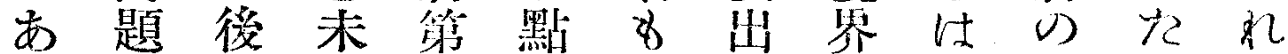

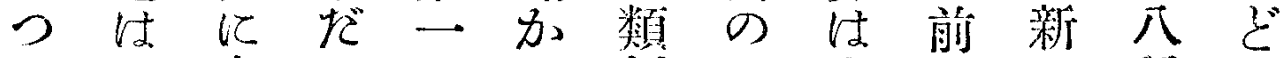

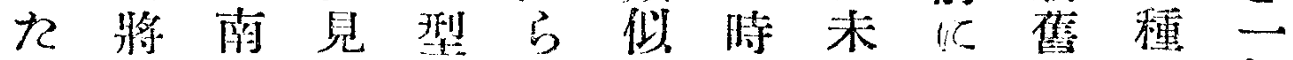

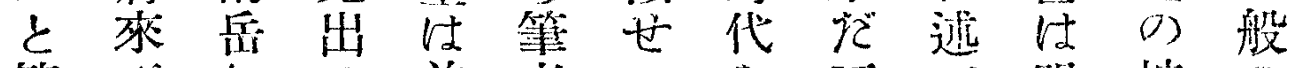

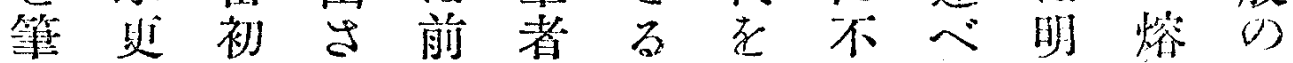




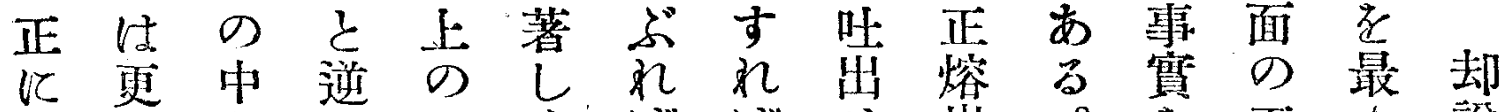

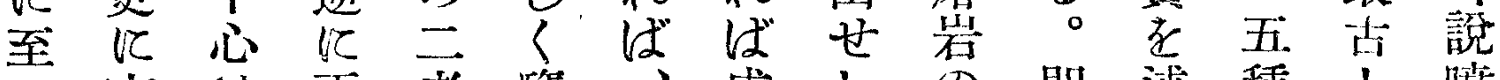

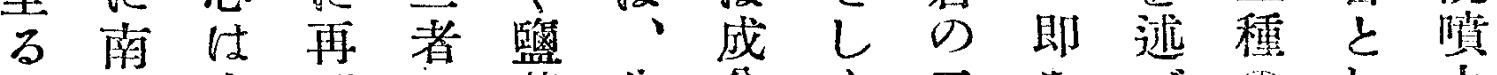

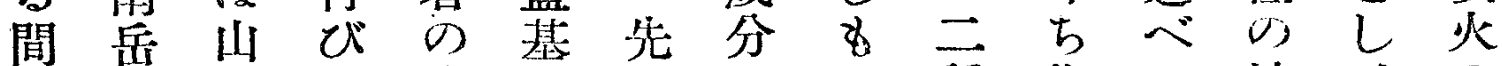
に熔腹北後性亏゙のの種化て 熔、の

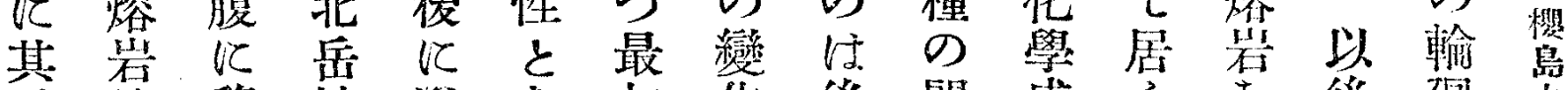

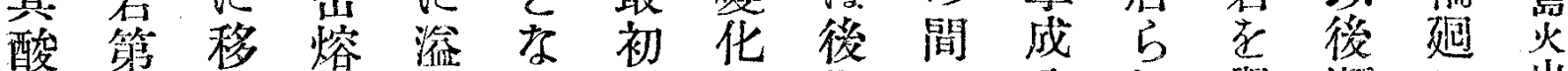

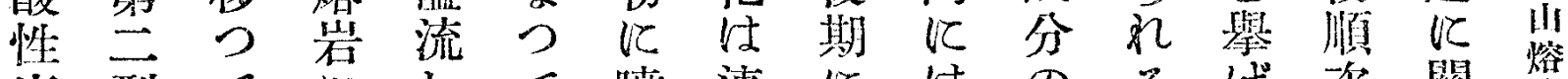

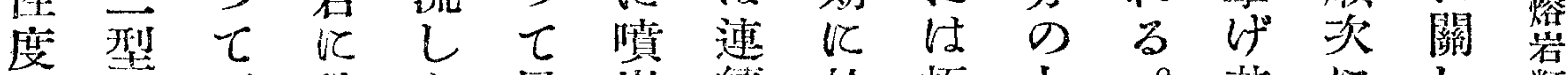

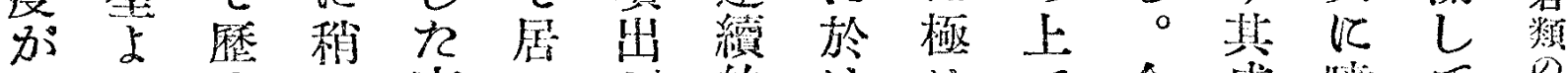

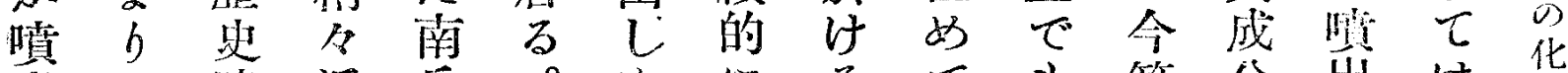

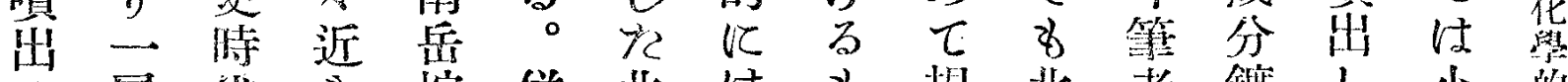

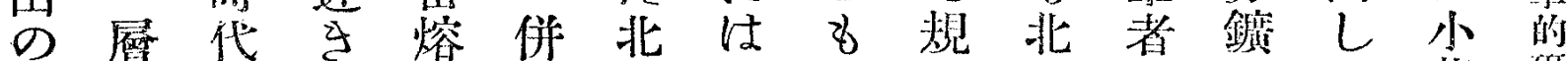

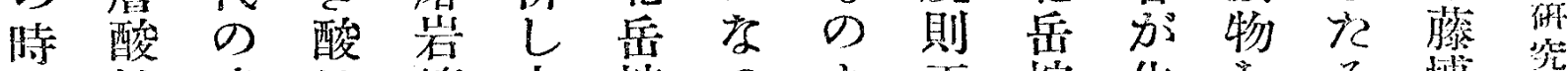

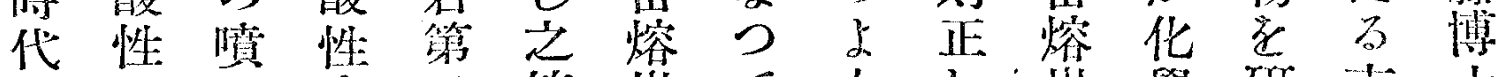

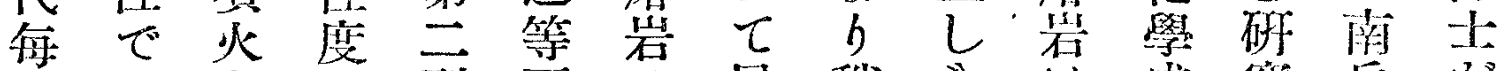

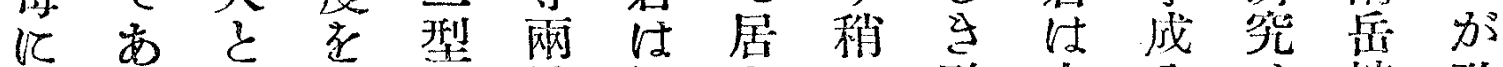

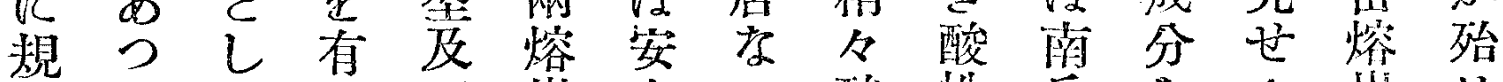
則 $\tau \tau$ 寸 び岩 山 正全現る中㤌贸。性度熔調れ!て

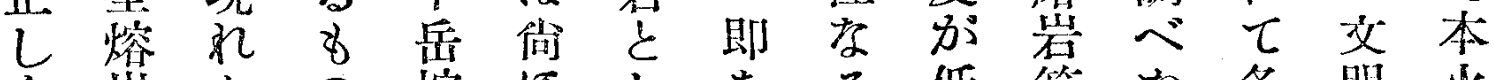
く紧れの熔医しちる低第九各明火

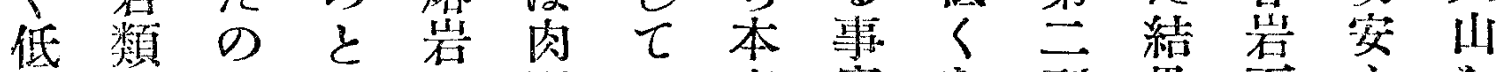
下中でなは眼は章曾な型果石永を

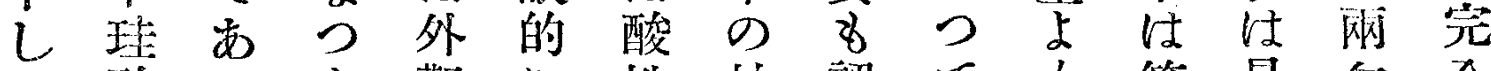
七酸るれ觀に性始認て b第最年全

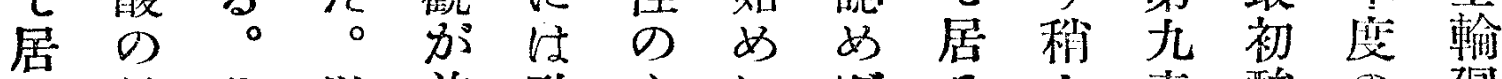

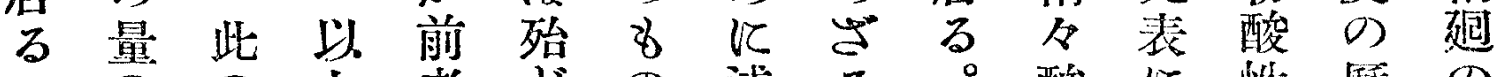
このの上者どの拈る。酸に性歴の

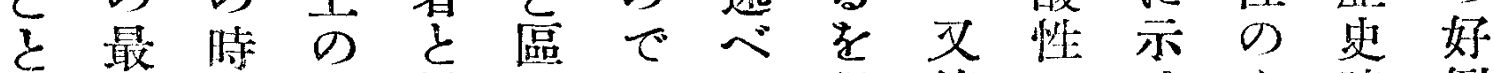

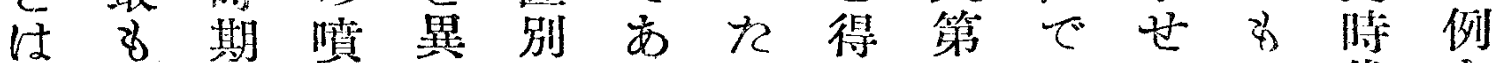

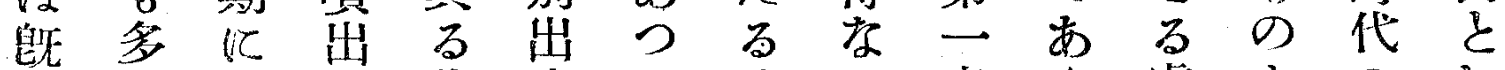

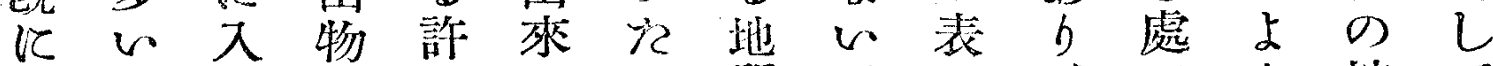

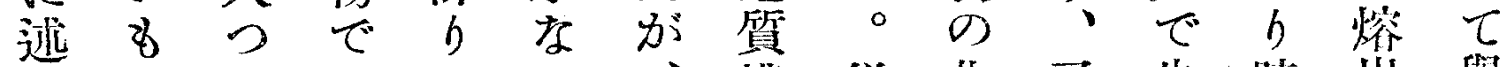

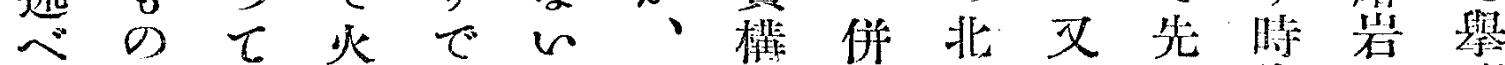
れでの山存位次造し岳文生代道け 處あ最のく類でに熔熔明のとにら

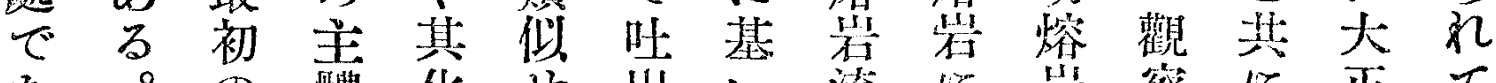
あ。の體化せ出心流仙宕祭に正て

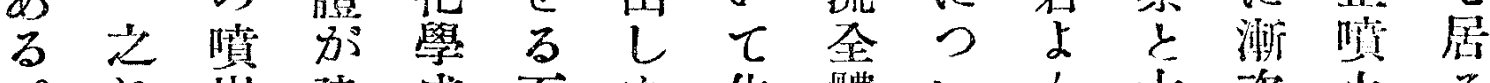
。机出建成石た化體的的大次火炎 要よ物設分理南學只こ安體監の 。六

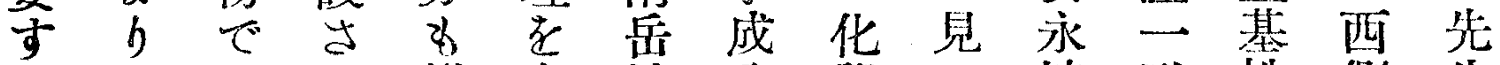
る 安あれ變有熔分學る 熔致性侧生

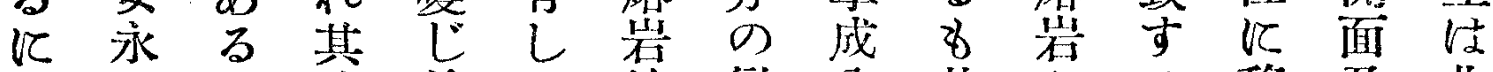
本を 文後前七第變 分 其をる移及北 火經明壮の居一化学初經名化び岳 山て 熔活場る 型を通期ての专東熔

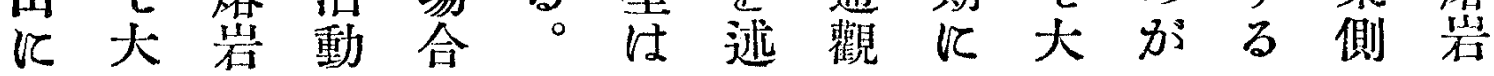


再す部型蹛 例化の成

びれに学外老成分以

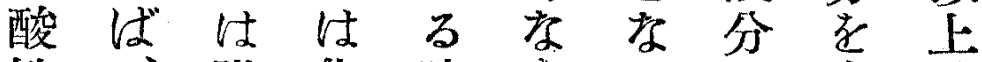

性、唯化時々儿加有述

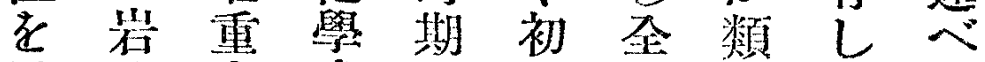

增獎力成圭期體似之來

眗し橧的分地にと妾

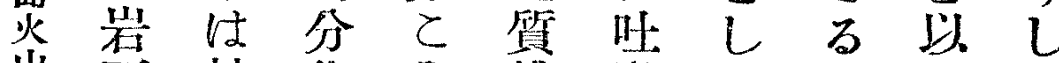

昸石弦化之程出

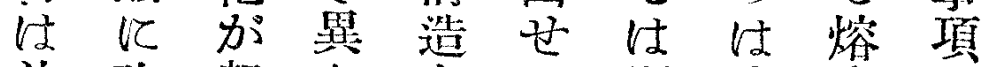

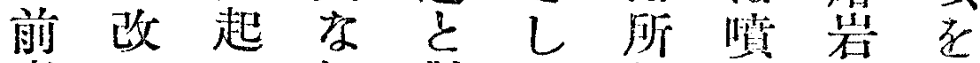

者めつれ對 8 謂出流簡

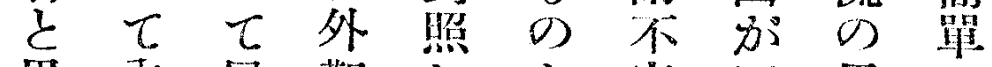

黑内共 觀 しょ完同 黑

孝部 た 極 $\tau$ b全時同 纆

る 28 女晃後輪代を 女

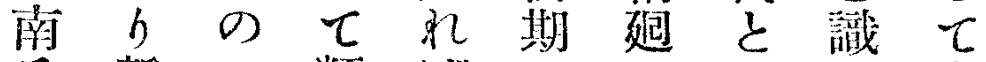

底新で類ばにを見別本

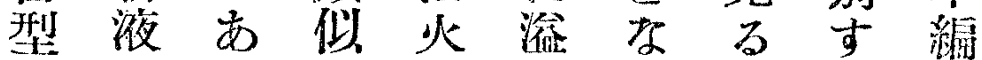

との

な注うる發也地重結

つ大。北充し扂で要び

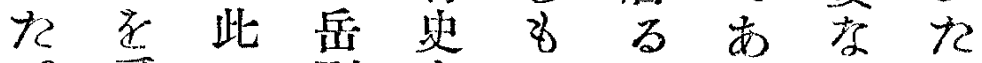

受の型上の 。る。

岩け後のの程侀。栖と

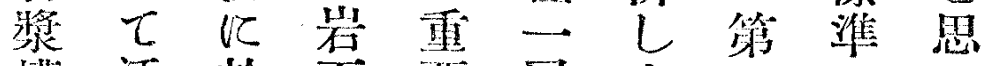

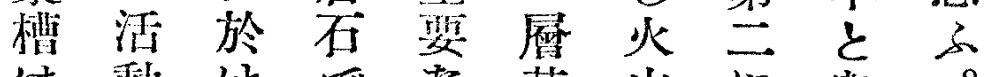

㤌動けで基山に疗。

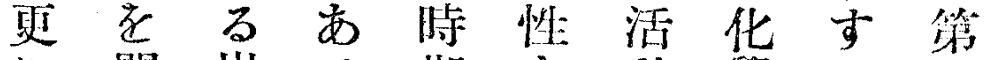

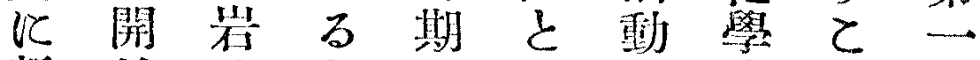

新始獎少儿学成とに

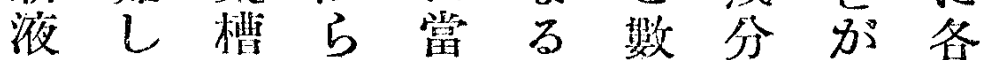

の社去つ倾资の出時

注のの等 て 向に變爽代

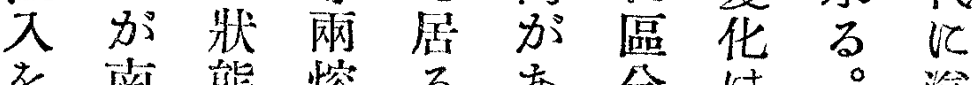

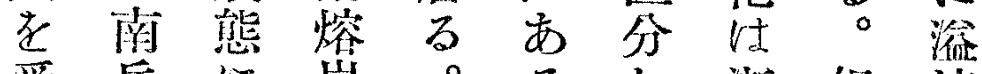

受岳に碞。ると澌但流

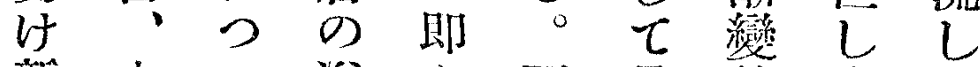

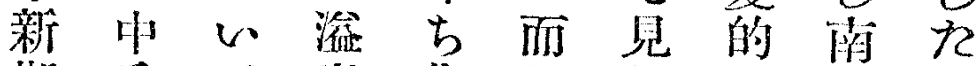

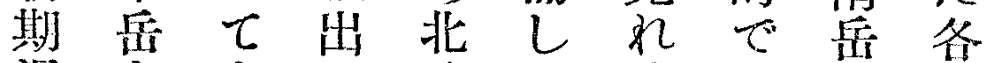

洮子小也岳てば度熔熔

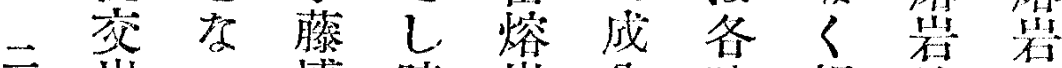

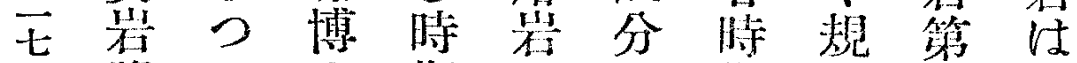

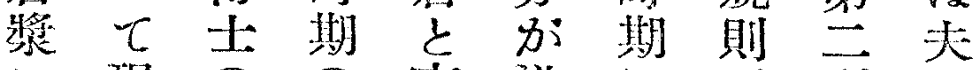

に現の南逆江正型々

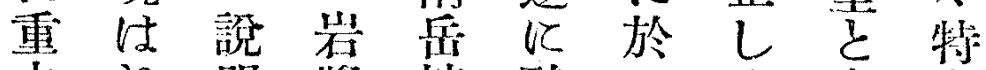

力れ 明浆熔 酸 $\tau<中$ 有

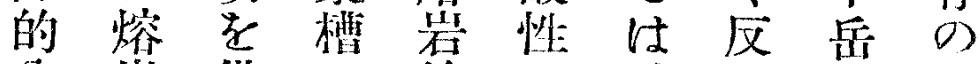

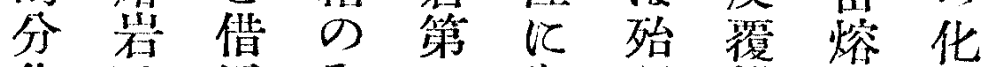

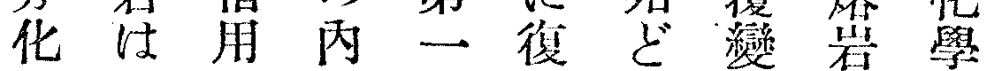

正定 通 於

しの じて

く順て は

反序見賁

復に机火

せ起ばの

るつ不㭙

總 事 $\tau$ 連 期

實居 䋶 及

飞的 び

認乙で地

括めと亦點

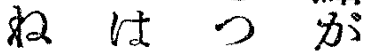

ば第て 異

奖九所症

ら表 謂る

欢䨿完に

儿圣 應

前 签

說 起 $\tau$

明家 其

の学都

示 L 度

寸 $\tau$ 渴

通居下

らなせ

で

あの熔

つで倠

て あ 流

各る寻

熔 低

宕 併 學

流 乙 成

の 又 分

洔 基注

代 㱍 赏

化化

上注 㜻

百沋化

化 乙

成不 8

分 䙺 其

D 則 㜻

签で 化

花柆㤝

壮な全

规々體

則 - 


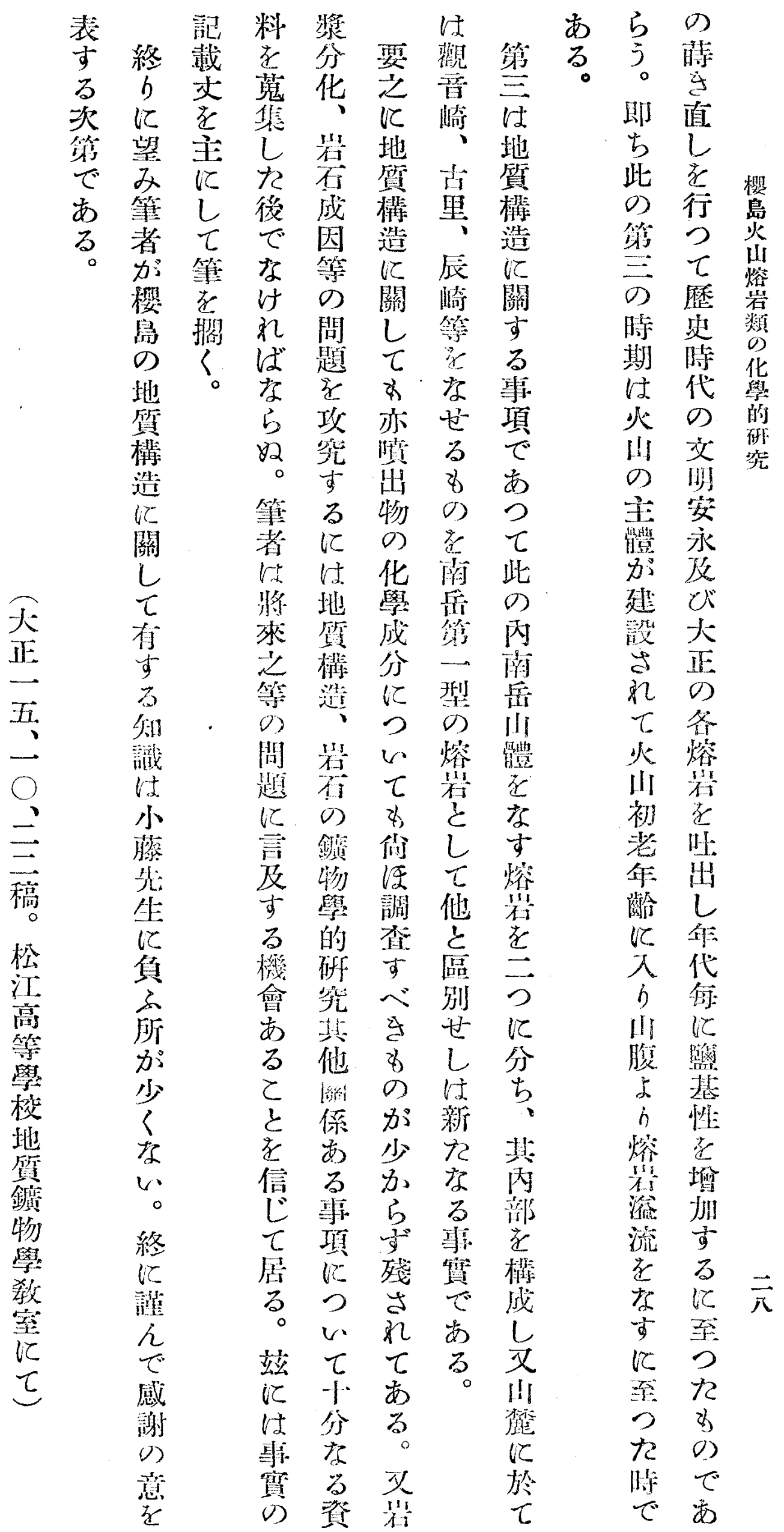

